\title{
Article \\ Ground Penetrating Radar Survey of the UNESCO Painted Churches in the Troodos Region (Cyprus)
}

\author{
William L. Mitchell ${ }^{1}$, Dante Abate ${ }^{2, *}$,, Kevin S. Colls ${ }^{1}$, Marina Faka ${ }^{2}$, Caroline Sturdy Colls ${ }^{1}$ \\ and Nikolas Bakirtzis ${ }^{2}$ \\ 1 Centre of Archaeology, Staffordshire University, Stoke on Trent ST4 2DE, UK; \\ william.mitchell@staffs.ac.uk (W.L.M.); kevin.colls@staffs.ac.uk (K.S.C.); c.sturdy-colls@staffs.ac.uk (C.S.C.) \\ 2 Science and Technology in Archaeology and Culture Research Center, The Cyprus Institute, \\ Nicosia 2121, Cyprus; m.faka@cyi.ac.cy (M.F.); n.bakirtzis@cyi.ac.cy (N.B.) \\ * Correspondence: d.abate@cyi.ac.cy; Tel.: +357-2220-8724
}

check for updates

Citation: Mitchell, W.L.; Abate, D.; Colls, K.S.; Faka, M.; Sturdy Colls, C.; Bakirtzis, N. Ground Penetrating Radar Survey of the UNESCO Painted Churches in the Troodos Region (Cyprus). Heritage 2022, 5 , 260-285. https://doi.org/10.3390/ heritage 5010014

Academic Editors: Francesco Soldovieri and Nicola Masini

Received: 23 December 2021

Accepted: 19 January 2022

Published: 25 January 2022

Publisher's Note: MDPI stays neutral with regard to jurisdictional claims in published maps and institutional affiliations.

Copyright: (c) 2022 by the authors. Licensee MDPI, Basel, Switzerland. This article is an open access article distributed under the terms and conditions of the Creative Commons Attribution (CC BY) license (https:/ / creativecommons.org/licenses/by/ $4.0 /)$.

\begin{abstract}
In the framework of the IH-AT (Invisible Heritage Analysis and Technology) project, a cluster of churches ranging from the 11th to the 16th centuries, located in the Troodos Mountain range of Cyprus, designated by UNESCO as World Heritage monuments, were investigated using NonDestructive-Techniques (NDT) (geophysical and topographic survey), 3D modelling and visualisation methods, contextualised and interpreted by art-historical and archaeological research. A geophysical survey, performed using a Ground Penetrating Radar (GPR), specifically aimed to confirm the presence or absence of buried features of archaeological interest at each of these sites, in particular, evidence of monastic complexes and buildings that used to surround preserved churches. This paper describes the preliminary results of this survey and some initial interpretations concerning what new information can be discerned about the now lost monastery complexes, in advance of future excavation.
\end{abstract}

Keywords: ground penetrating radar; archaeology; Byzantine church; monastery; UNESCO; Cyprus

\section{Introduction}

In 1985, the United Nations Educational, Scientific and Cultural Organization (UNESCO) inscribed the "Painted Churches in the Troodos Region" of the Republic of Cyprus on the World Heritage List. The latter included nine Byzantine and Post Byzantine churches of the Troodos Mountain range, to which a tenth church was added in 2001 [1]. The humble, yet well-preserved, rural churches of the region of Troodos are considered among the best examples of Byzantine and Medieval religious art in Cyprus and the broader Eastern Mediterranean region. With dates ranging from the eleventh through the sixteenth century, the ten chapels included in the UNESCO monument preserve rich wall-painting decorative programs which stand out for their high quality and style [2,3]. They mirror artistic developments and influences that help to shed light onto the routes of communication and the related cultural interconnections across the Eastern Mediterranean. They reflect the investment of the Byzantine state in Cyprus as well as the subsequent engagement of the Latin and Crusading rulers of the island in the cultural life of local communities, expressed through donations and support to Orthodox monasteries. The architecture of these churches echoes evolutions in Middle Byzantine architecture but also local and regional responses to the religious needs of patrons and rural societies. Using local building materials and featuring stone masonries and brick, early examples were built following standard Byzantine architectural typologies such as cruciform and cross-in-square buildings topped with beautiful domes [4,5]. In time, elaborate wooden roofs were constructed over existing domes and later this completely replaced earlier roofing, becoming a staple of ecclesiastical architecture of the period [6]. Church typologies were simplified with local rubble masonry techniques becoming standard. 
In addition to the study of the art of these chapels, little is known about their original monastic contexts as most of these church buildings formed part of much larger monastery complexes. The lack of systematic archaeological work around these rural churches has denied a better understanding of the complex histories of the now lost Byzantine monasteries. Historic photographs, descriptive accounts and sketches provide a limited resource to help us reconstruct the monastic communities that sustained networks of cult and worship around the ten churches of the UNESCO list, all of which are now solitary chapels (with the exception of Agios Ioannis Lambadistis monastery near Kalopanayiotis), deprived of their architectural and cultural settings.

From the aforementioned list of ten churches, four were built as private chapels and are today embedded in the urban fabric of the villages in which they reside. The remaining six were monasteries, five of which were identified as suitable for Ground Penetrating Radar (GPR) surveys based on reconnaissance site visits, photographic site documentation, the analysis of historical sources and the study of historical images (Figure 1).

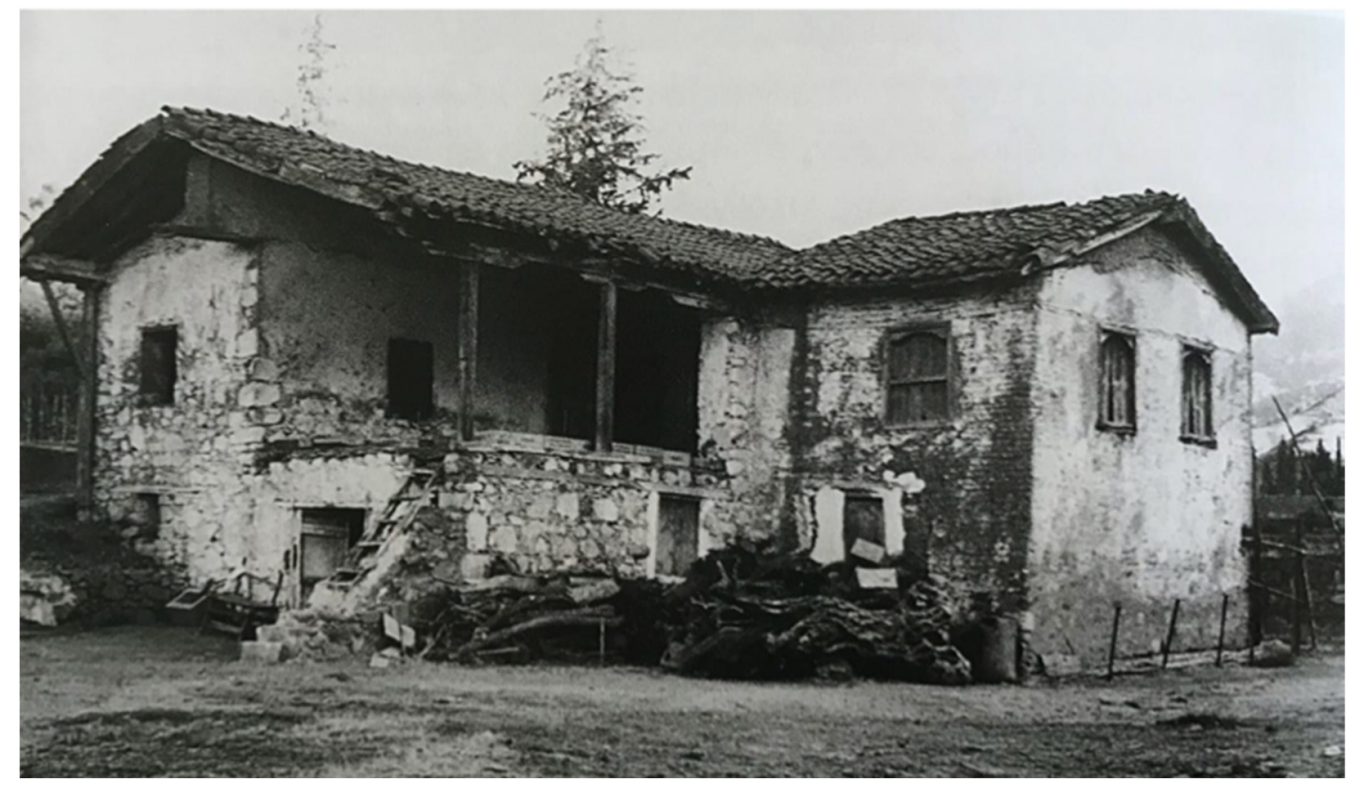

Figure 1. Panagia tis Podithou Monastic Cells today lost, 1950 historical image, Department of Antiquities of Cyprus.

Each of these sites (Agios Nikolaos tis Stegis (St. Nikolas of the Roof), Panagia Phorviotissa (Panagia tis Asinou), Panagia tou Araka, Panagia tis Podithou and Stavros tou Agiasmati) was chosen for its potential to have preserved underground architectural remains from buildings belonging to the original monasteries (Figure 2). These remains were expected to be either former monastic buildings (including former crypts or vaults) or burials, being that these were monastic grounds. The remaining site, Agios Ioannis Lambadistis, was excluded from the geophysical survey since the whole monastery is still preserved and in use.

It is worth mentioning that from the above UNESCO list, buildings related to earlier monasteries (either original structures or reconstructions) are present at only three sites: at the Panagia tou Araka, Agios Ioannis Lambadistis and Stavros tou Agiasmati.

At the current stage of the project, this paper focuses only on geophysical prospection of the sites, with the aim of providing the authorities with an overview of the possible underground scenarios that may be ground-truthed in the future. The decision to undertake excavations at these sites now lies with the Department of Antiquities of Cyprus, which has the sole responsibility for the management of the archaeological heritage of Cyprus. 


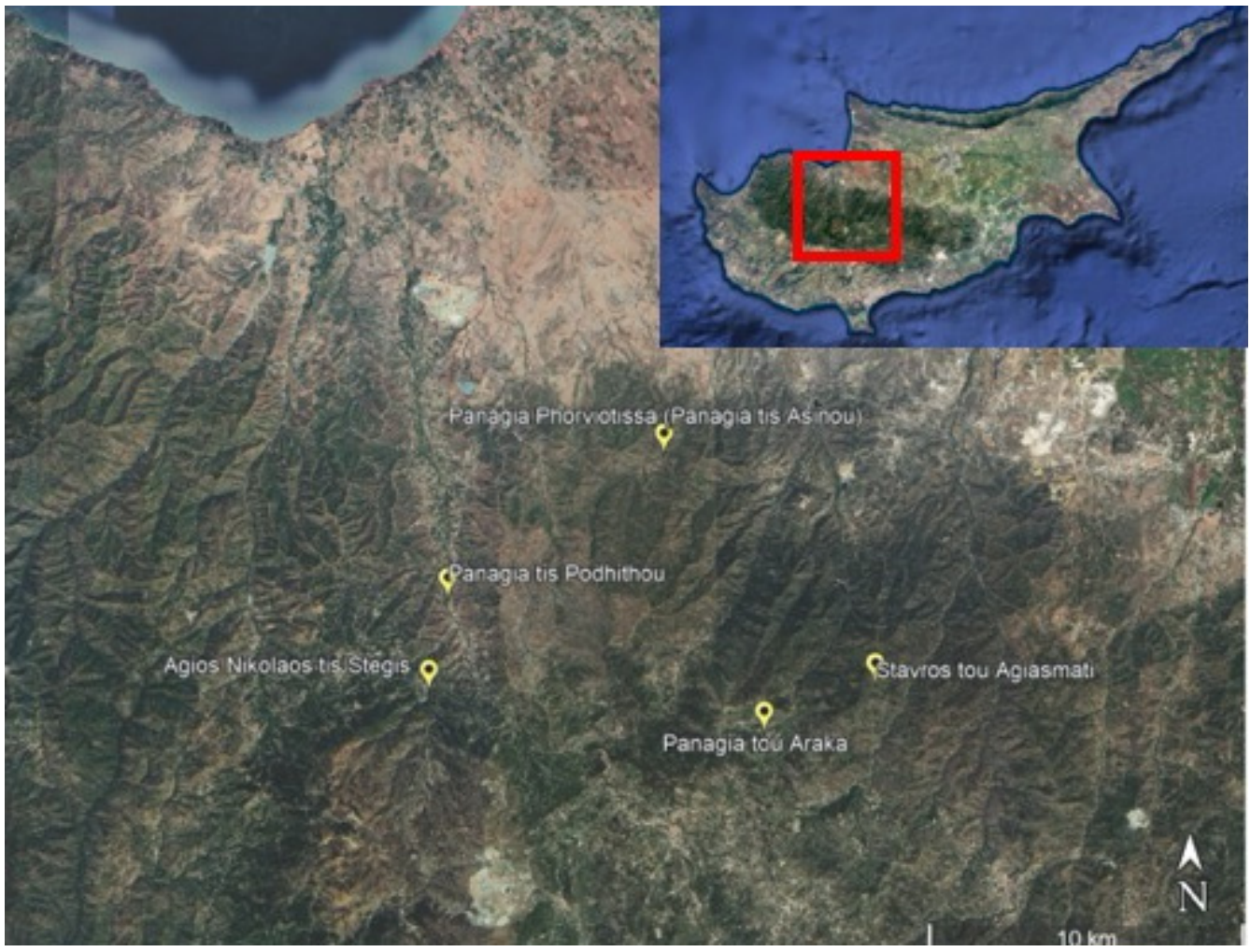

Figure 2. Site map of church locations included in the GPR survey (Google Earth Open Sources).

\section{Materials and Methods}

A team from the Science and Technology in Archaeology and Culture Research Centre (STARC) and its Andreas Pittas Art Characterization Laboratories (APAC Labs) of the Cyprus Institute (CyI) studied the five churches in the mountainous Troodos region and collaborated with the Centre of Archaeology at Staffordshire University to undertake Ground Penetrating Radar (GPR) surveys between the 5th to the 9th of October 2020 at each location. GPR is now a well-established technique for the identification and investigation of buried remains. This method functions by emitting reflections or attenuations of electromagnetic (radar) signals from a roving antenna [7-9]. The responses to the reflections, which are affected by the physical properties of the subsurface and any buried features within it, are then recorded and visualised in 2D and 3D data plots that can be analysed to determine the presence, size and nature of buried remains. An advantage of GPR is that the emitted signal is capable of propagating through most materials and, therefore, this method can be used in a variety of landscapes and on a range of surfaces (e.g., over concrete and in rural areas), providing there are not too many obstructions. This was a particular advantage at the sites in the Troodos region due to the varying man-made and natural landscape features present, sometimes within the same site. These same conditions rendered the use of electrical resistance and magnetometry survey ineffective. Unlike other geophysical methods, GPR is also able to provide true depth information, facilitating more detailed interpretations of underlying strata and archaeological remains. A more detailed overview of this method can be found in $[8,9]$. Geophysical methods on the whole are able to assist in locating and establishing the extent of buried features and can also give an indication of areas to avoid during later investigations. Later, destructive archaeological excavation can therefore be targeted and limited to the most significant, or likely, areas of interest.

It was anticipated that the collection of GPR data may be hindered by the soil of the Troodos region which is known to be clay-rich with substantial rubble inclusions, characteristics also found elsewhere on the island of Cyprus [10-12]. There was also known to be significant moisture content due to the presence of clay. This issue was compounded by the lower-than-average rainfall experienced throughout Cyprus during the preceding months 
of 2020 [13]. It has previously been suggested by researchers that these conditions, which can affect the penetration depths of the receiver, are ill-suited for GPR investigations [14]. Additionally, it has also been concluded that seasonal moisture content of the soil can have a substantial impact on identifying and interpreting archaeological features using GPR [15]. However, on sites in Cyprus, the use of lower frequency antennas alongside practicable transect intervals has previously been shown to provide data resolution comparable with higher frequency GPR models, although archaeological investigations which have used GPR survey are limited and therefore detailed comparison of datasets requires further work on the subject [16].

Hence, in this study, a lower frequency antenna $(350 \mathrm{MHz})$ with a larger sampling concentration, adjusted to each individual grid, was selected to counteract the issues with the underlying geological subsoils and facilitate an analysis of the layers in which archaeological remains may reside.

A preliminary site visit and indications from the desk-based assessment phase of the project suggested that the archaeological remains sought most likely existed at depths of less than $4 \mathrm{~m}$. This led to the use of a Geophysical Survey Systems, Inc. (Nashua, NH, USA) (GSSI) SIR-4000 GPR with a $350 \mathrm{MHz}$ digital antenna with hyperstacking technology to examine the five church landscapes. Radar reflections were collected as 32-bit data in a time range of $80 \mathrm{nS}$ at 512 samples/scan and with a scan rate of 60 scans/metre. Prior to commencing each survey, depth calibration and dielectric constant modification were carried out in accordance with the procedures outlined in [17]; in short, the depth value was adjusted over a known target and the vertical scale and dielectric constant were automatically adjusted. The gain settings were also manually adjusted according to the ground conditions experienced on each site. Data collection parameters are summarised in Table 1. In summary, data were collected using a calibrated survey wheel in parallel profile lines spaced at $0.5 \mathrm{~m}$ traverse intervals, orientated to the landform. The only exception was Panagia tis Podithou, where $1 \mathrm{~m}$ intervals were used to allow a larger area $(64 \times 34 \mathrm{~m})$ to be surveyed in the time available. Combining all five sites, an area of $5819.5 \mathrm{~m}^{2}$ was investigated. All work was completed according to guidelines published by the Chartered Institute for Archaeologists [18].

Each survey was realised in a grid system and the survey areas were recorded using differential GPS (Global Positioning System) in the WGS 84 UTM 36N.

The GPR survey grids were positioned to:

(1) Include as much of the areas of interest as possible;

(2) Account for obstacles within the survey area, such as vegetation and structures;

(3) Focus on potential areas identified in documentary and cartographic sources identified during the previous historical review phase of the project [19].

The position of the GPR grids and other features of interest within it (e.g., visible concrete, gravel, vegetation, spoil heaps, etc.) were recorded using a Leica GPS base station receiver and rover. Knowing the locations of above-ground features such as trees/stumps, spoil, concrete, gravel, metal, etc., assisted in the interpretation of the GPR data. Prior to the GPR work being undertaken, movable surface obstacles (such as large rocks) were removed to enable greater survey coverage. 
Table 1. Ground Penetrating Radar Survey details (Staffordshire University-The Cyprus Institute).

\begin{tabular}{|c|c|c|c|}
\hline Scheme & Survey Area & No. of Profiles & Method \\
\hline \multirow{2}{*}{ Agios Nikolaos tis Stegis } & $\begin{array}{l}\text { Grid 1. } 39 \text { m length } \times 12 \mathrm{~m} \\
\text { width }\end{array}$ & 78 profiles & $\begin{array}{l}\text { Parallel data collection with } 0.5 \mathrm{~m} \text { traverse } \\
\text { intervals. Direction of GPR collection } \\
\text { south-west to north-east. }\end{array}$ \\
\hline & $\begin{array}{l}\text { Grid 2. } 11 \text { m length } \times 10 \mathrm{~m} \\
\text { width }\end{array}$ & 22 profiles & $\begin{array}{l}\text { Parallel with } 0.5 \mathrm{~m} \text { traverse intervals. } \\
\text { Direction of GPR collection east to west. }\end{array}$ \\
\hline \multirow{3}{*}{$\begin{array}{c}\text { Panagia Phorviotissa (Panagia } \\
\text { tis Asinou) }\end{array}$} & $\begin{array}{c}\text { Grid } 1.34 .5 \text { m length } \times 27 \mathrm{~m} \\
\text { width }\end{array}$ & 91 profiles & $\begin{array}{l}\text { Parallel data collection with } 0.5 \mathrm{~m} \text { traverse } \\
\text { intervals. Several profile lines were split } \\
\text { due to non-movable obstacles. } \\
\text { Direction of GPR collection north to south. }\end{array}$ \\
\hline & $\begin{array}{c}\text { Grid 2. } 22.5 \text { m length } \times 4 \mathrm{~m} \\
\text { width }\end{array}$ & 9 profiles & $\begin{array}{l}\text { Parallel data collection with } 0.5 \mathrm{~m} \text { traverse } \\
\text { intervals. } \\
\text { Direction of GPR collection north to south. }\end{array}$ \\
\hline & $\begin{array}{c}\text { Grid 2. } 22.5 \text { m length } \times 4 \mathrm{~m} \\
\text { width }\end{array}$ & 32 profiles & $\begin{array}{l}\text { Parallel data collection with } 0.5 \mathrm{~m} \text { traverse } \\
\text { intervals. Direction of GPR collection north } \\
\text { to south. }\end{array}$ \\
\hline Panagia tou Araka & $26 \mathrm{~m}$ length $\times 25 \mathrm{~m}$ width & 53 profiles & $\begin{array}{l}\text { Parallel data collection with } 0.5 \mathrm{~m} \text { traverse } \\
\text { intervals. Direction of GPR collection north } \\
\text { to south. }\end{array}$ \\
\hline \multirow{3}{*}{ Panagia tis Podhithou } & $\begin{array}{l}\text { Grid 1. } 64 \text { m length } \times 35 \mathrm{~m} \\
\text { width }\end{array}$ & 20 profiles & $\begin{array}{l}\text { Parallel data collection with a } 1 \mathrm{~m} \text { traverse } \\
\text { interval. } \\
\text { Direction of GPR collection west to east. }\end{array}$ \\
\hline & $\begin{array}{l}\text { Grid 2. } 25 \text { m length } \times 19 \mathrm{~m} \\
\text { width }\end{array}$ & 20 profiles & $\begin{array}{l}\text { Parallel data collection with a } 1 \mathrm{~m} \text { traverse } \\
\text { interval. } \\
\text { Direction of GPR collection south to north. }\end{array}$ \\
\hline & Grid 3. $26 \mathrm{~m}$ length $\times 25 \mathrm{~m}$ & 51 profiles & $\begin{array}{l}\text { Parallel data collection with a } 1 \mathrm{~m} \text { traverse } \\
\text { interval. } \\
\text { Direction of GPR collection west to east. }\end{array}$ \\
\hline \multirow[t]{2}{*}{ Stavros tou Agiasmati } & $\begin{array}{l}\text { Grid } 1.11 \text { m length } \times 10 \mathrm{~m} \\
\text { width }\end{array}$ & 26 profiles & $\begin{array}{l}\text { Parallel data collection with } 0.5 \mathrm{~m} \text { traverse } \\
\text { intervals. } \\
\text { Direction of GPR collection south-east to } \\
\text { north-west. }\end{array}$ \\
\hline & $\begin{array}{l}\text { Grid 2. } 16 \text { m length } \times 4 \mathrm{~m} \\
\text { width }\end{array}$ & 9 profiles & $\begin{array}{l}\text { Parallel data collection with } 0.5 \mathrm{~m} \text { traverse } \\
\text { intervals. } \\
\text { Direction of GPR collection south-east to } \\
\text { north-west. }\end{array}$ \\
\hline
\end{tabular}

Following the survey, the GPR data were processed using RADAN software, a fullfeatured platform for post-processing GPR data. The following processing sequence was used: time zero (the process of setting the position of the ground surface), background removal (the deletion of horizontal bands in the data which derive from external noise) and high/low pass filters (enabling the selection and removal of certain frequency ranges). Data interpretation was then undertaken using the individual section profiles (generated from each individual line of data collected) and depth timeslices (generated by combining all the individual profile lines into one 3D grid file). The GPS and the GPR data were both overlaid onto aerial images and mapping data within ArcGIS to facilitate comparisons between these datasets.

\section{Results and Discussion}

The Ground Penetrating Radar surveys of the former Byzantine monasteries and associated churches were undertaken at five separate locations in the mountainous region of Troodos. Each site location (sites 1-5 below) differed in site topography, surface features, 
geological attributes and background information which influenced the methodology employed in terms of grid positioning and survey coverage. During the post-processing of the GPR data, several surface and subsurface features were observed, the most significant of which are described in the following section. The data resulting from the GPR survey included both 2D section profiles and depth timeslices. Rectilinear and linear high amplitude reflections along with positive and negative response anomalies were present within the data at a number of the sites surveyed.

\subsection{Site 1: Agios Nikolaos tis Stegis, Kakopetria, Subsurface Features}

Constructed in the 11th century, Agios Nikolaos tis Stegis, near the village of Kakopetria, is considered to be the earliest of the ten churches included in the UNESCO listing. The cross-in-square with narthex, domed structure used to be the Katholikon church of a monastic complex which was abandoned sometime in the mid-19th century and did not survive. The large two-sided wooden roof over the dome was constructed after the completion of the domed church to offer additional protection [2]. The church preserves important wall-painting cycles from the 11th, 12th, 13th/14th, late 14th and 17th centuries. A small structure covered with a two-sided wooden roof located about fifty meters south of the church likely represents a surviving monastic building. Aside from this, we can only speculate about the actual size and organisation of the monastic complex that once existed on the site, as no additional historical information survives (Figure 3).

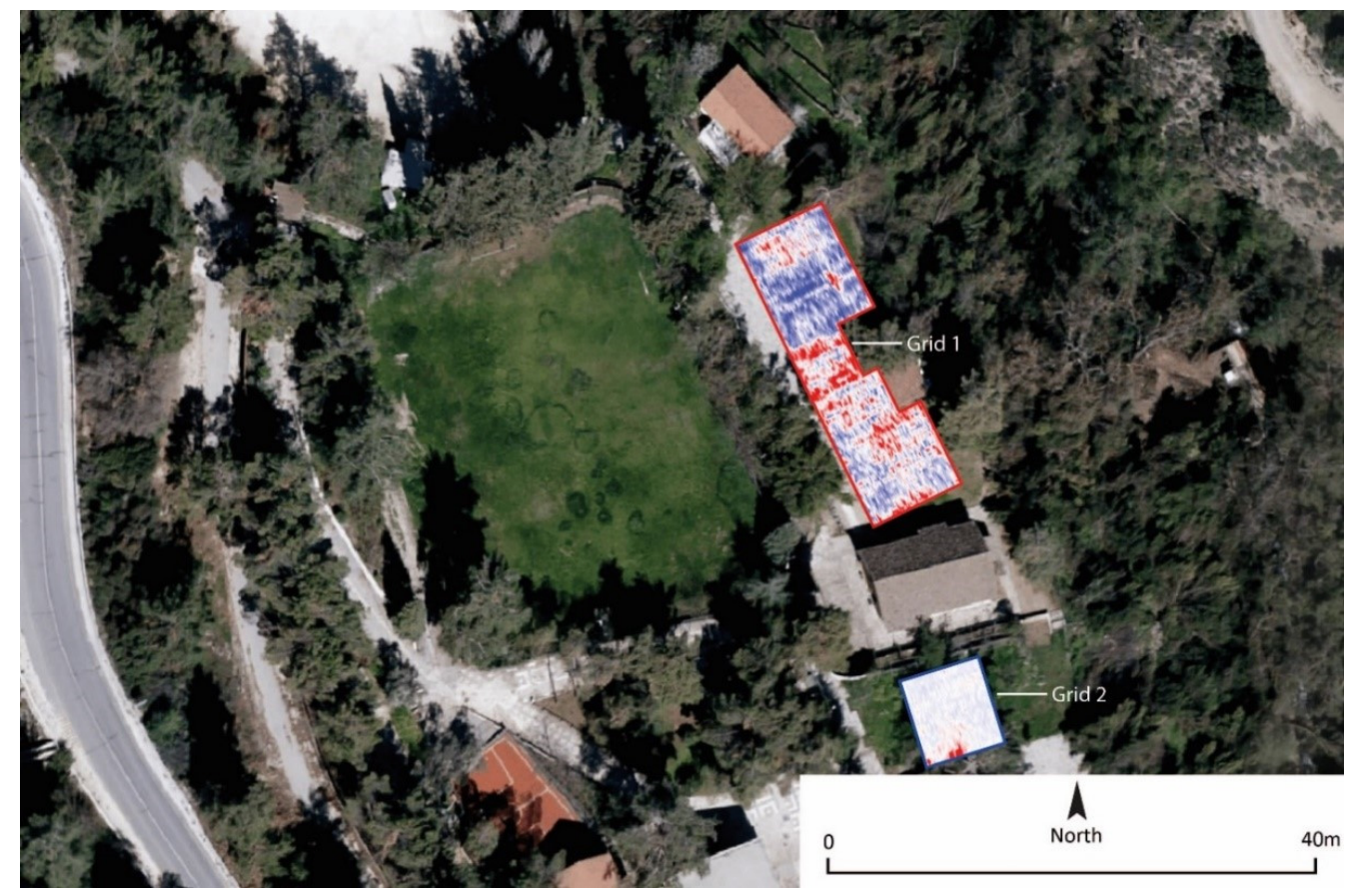

Figure 3. Agios Nikolaos tis Stegis (building between the grids). Grids 1 (north) and 2 (south) including GPR data (Staffordshire University, The Cyprus Institute).

Two survey grids were undertaken on the site, the purpose of which was to identify buried structural remains or potential burials relating to the now lost buildings. The larger of the two (Grid 1-39 m length $\times 12 \mathrm{~m}$ width) was located to the north of the church upon short grass. A large modern building was located within the north-eastern edge of the grid.

The GPR survey of Grid 1 confirmed the existence of strongly reflective natural geological material across the area which was not conducive to the efficient collection of GPR data. The results suggest that undisturbed natural geology is present from around $1 \mathrm{~m}$ beneath ground level at this site. Observation of the topography of the area surrounding the church suggests that significant ground alteration has occurred in the past, resulting in pronounced terracing and areas of levelled material. This is particularly obvious within 
Grid 1 where there are steep terraces on both the northern and southern sides and where the ground appears to have been deliberately flattened and then landscaped (Figures 3 and 4).

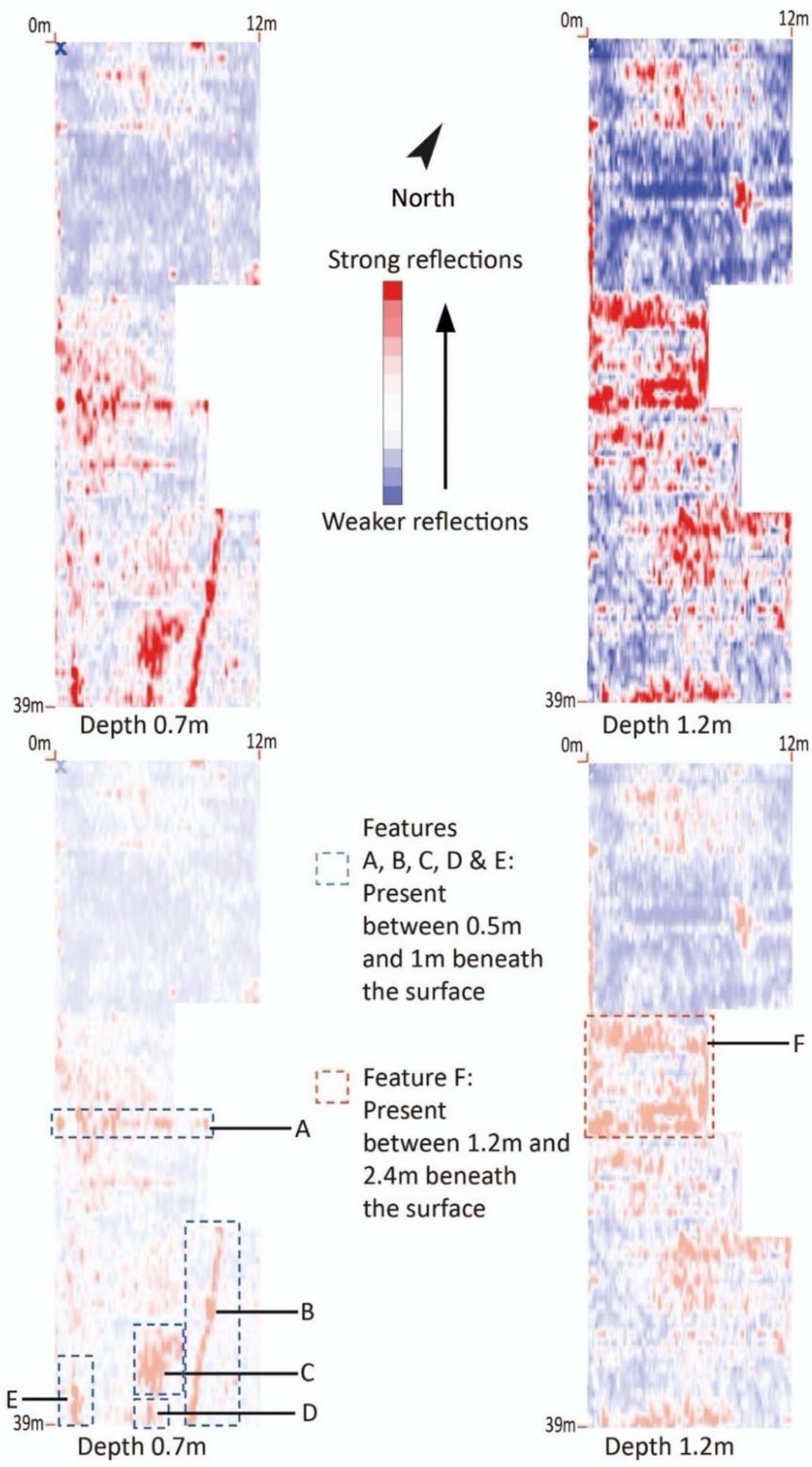

Figure 4. Two GPR timeslices $(0.7 \mathrm{~m}$ and $1.2 \mathrm{~m})$ from Agios Nikolaos tis Stegis, Grid 1. Processed images (top left and right), processed images with annotations (bottom left and right) showing features identified during the survey.(Staffordshire University, The Cyprus Institute). 
The majority of anomalies present in the location of Grid 1 are likely the result of laying service trenches in the modern period. None of the features are suggestive of earlier buried structural remains. A linear anomaly (Feature A), which ran south-west to north-east around the central area of the grid, was identified between $0.2 \mathrm{~m}$ and $0.8 \mathrm{~m}$ below ground level. Several other linear service trenches (Features B, D and E) were identified at the southern end of the site at around the same depth. Features $\mathrm{D}$ and $\mathrm{E}$ ran north-west to south-east, and Feature B ran in a continuous line from north to south from the current ticket office building. These features likely represented a service trench relating to the current ticket office building at the north-east of the site.

A further anomaly at this end of the grid (Feature C), which was probably related to linear anomaly $\mathrm{D}$, was identified at the same depth $(0.2 \mathrm{~m}$ to $0.8 \mathrm{~m}$ below ground level). This may also represent a larger discrete feature at this location.

A large area of strong reflections was present towards the centre of the survey area (Feature F). This anomaly was present at a significant depth beneath the surface (beginning at $1.2 \mathrm{~m}$ and ending around $2.4 \mathrm{~m}$ ). In plan, this feature appeared to be at least $6 \mathrm{~m}$ by $4 \mathrm{~m}$ in length although it continued outside of the grid to the north and south. The higher amplitude signals were likely to have been the edges of the anomaly, where the mixed signals within were likely to have been the homogenous material of a backfilled pit.

Fewer anomalies of significance were present within Grid 2. The grid, which was $11 \mathrm{~m} \times 10 \mathrm{~m}$, was located to the south of the church on a raised area of bare earth wasteground, with overgrowth of vegetation, having previously been cultivated. Three anomalies (Features A, B and C), which were present at the southern end of the trench as high amplitude signals, were present as a result of metal drain covers and disturbance from local electrical sources. These were present from between $0.4 \mathrm{~m}$ to $0.7 \mathrm{~m}$ below the surface (Figures 3 and 5).

A further anomaly, present towards the centre of the grid (Feature D), covered an area in plan of around $2 \mathrm{~m}^{2}$. This anomaly, likely to have been an area of general disturbance due to previous construction or agricultural development of the area, was present between $0.1 \mathrm{~m}$ and $0.7 \mathrm{~m}$ beneath the surface.

The GPR survey did not reveal compelling evidence for the location of any remains from the monastery that once existed at the site. With the exception of the small wooden roof building south of the Agios Nikolaos tis Stegis church, no other structure has been identified. It appears that any remains have been destroyed, disturbed or were rendered unreadable for GPR work, by the extensive modern construction works related to the creation of terraces to the north and the south of the church (the construction of adjacent summer camp facilities and the extensive parking and built access to the monument). Only systematic and targeted archaeological excavations would help shed light into the organisation of the original monastery which most likely was developed along the steep slope of the mountainous ravine where the present solitary church is located. 

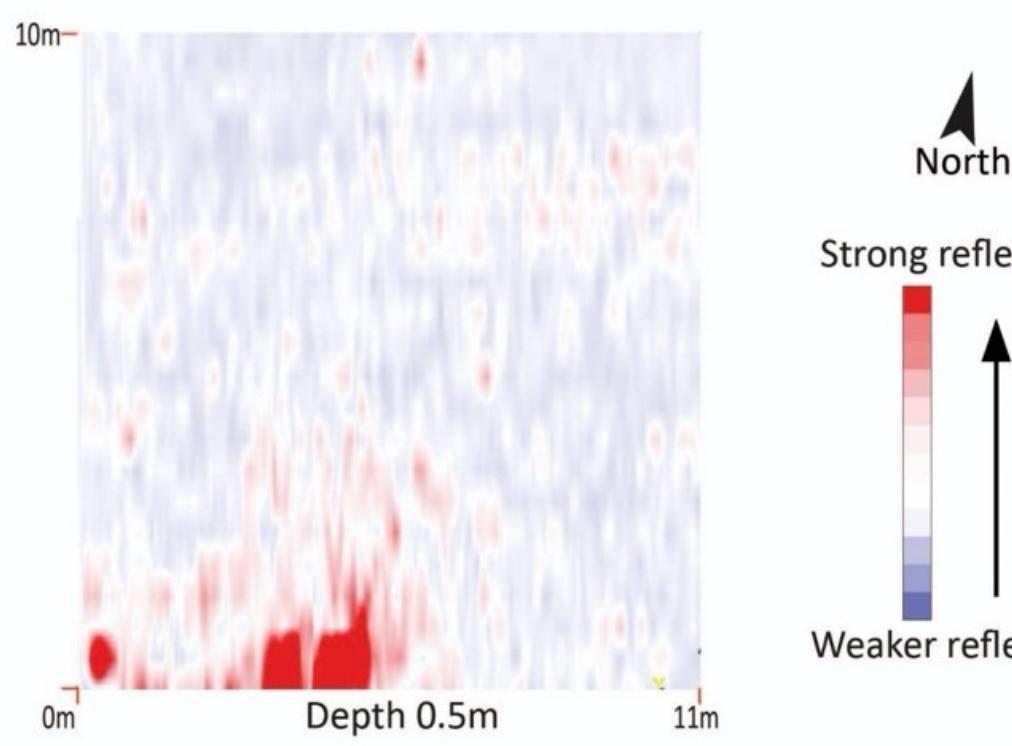

\section{Strong reflections}
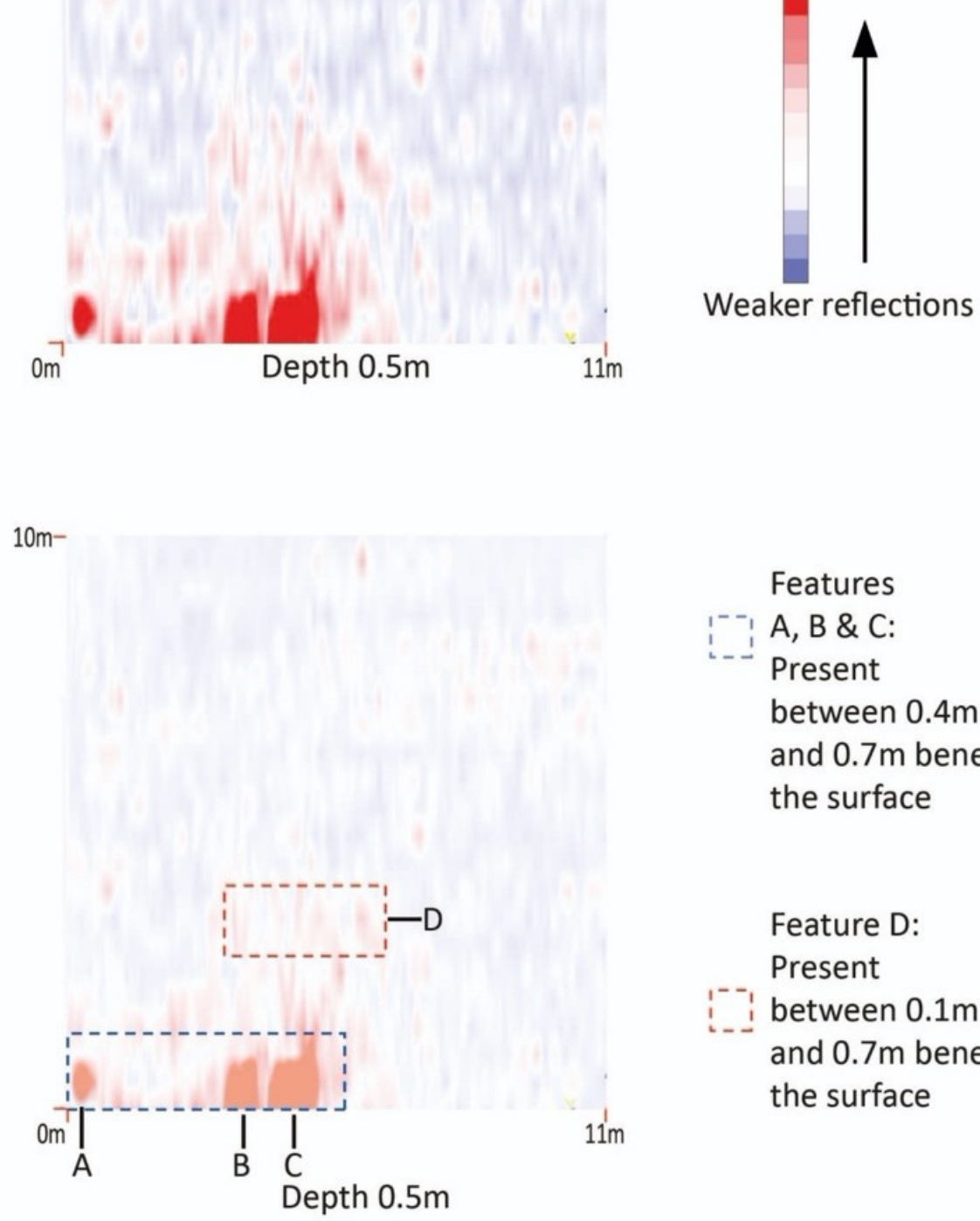

Features

A, B \& C:

Present

between $0.4 \mathrm{~m}$

and $0.7 \mathrm{~m}$ beneath

the surface

Feature D:

Present

between $0.1 \mathrm{~m}$

and $0.7 \mathrm{~m}$ beneath

the surface

Figure 5. GPR timeslice $(0.5 \mathrm{~m})$ from Agios Nikolaos tis Stegis, Grid 2. Processed image (top), processed image with annotations (bottom) showing features identified during the survey. (Staffordshire University, The Cyprus Institute).

\subsection{Site 2: Panagia Phorviotissa (Panagia tis Asinou), Nikitari, Subsurface Features}

Panagia Phorviotissa, also known as Panagia tis Asinou, is located near the village of Nikitari and is considered one of the most important examples of Byzantine and Medieval religious art in Cyprus dating from the 12th and the 14 th centuries $[2,19,20]$. It is a small church covered with a two-sided roof over its naos and a low dome over its narthex characterised by the apses protruding from its north and south sides. Like other Troodos rural chapels, it was originally part of a monastic complex which has not been preserved. According to the available sources, the monastery was abandoned in the 18th century. 
Restoration work in 1959 involved the removal of supporting piers added to the arch of the eastern apse. This period of restoration also involved changing the design of the roof for improved drainage, which drastically changed the appearance of the building [21]. During discussions with the local priest it was confirmed that construction work for a low wall around the church site in 2000 uncovered a series of tombs and artefacts, although the layout and location of these were not systematically recorded.

Three survey grids (Grids 1-3) were undertaken on the site, covering the majority of the walled enclosure surrounding the church. It was anticipated that buried structural remains or burials could be identified within the area (Figure 6). The ground within the enclosure was composed of loose dry earth with a significant amount of leaf litter on the ground surface. Grid 1 was split by the south side of the church, by a raised stone pathway of large flat stones in cement mortar. Several trees needed to be marked, as they were too wide to go around, resulting in the split survey lines. Floodlights were present in each corner of the site, for which power lines ran underground and several manhole covers were present.

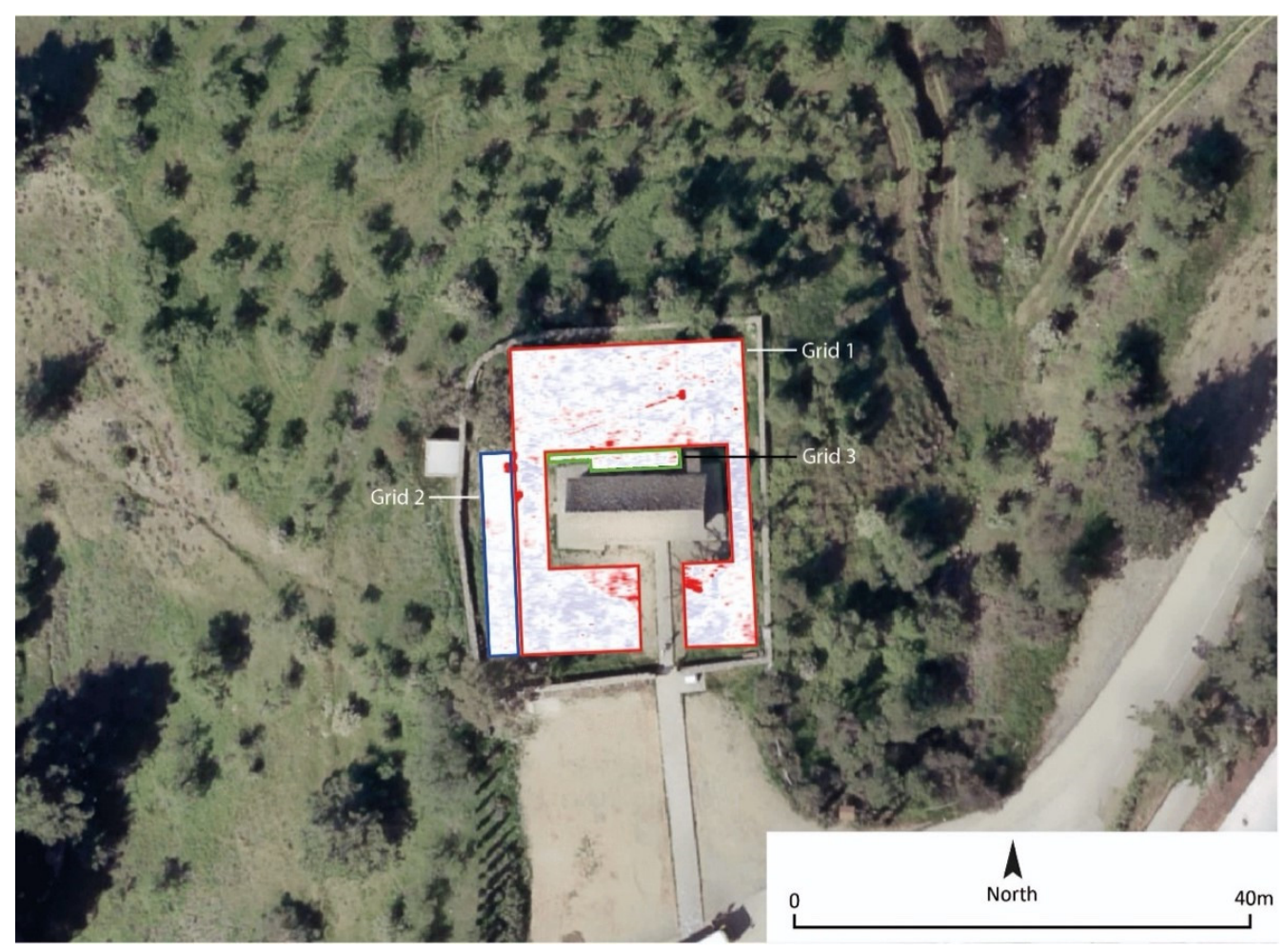

Figure 6. Panagia Phorviotissa (Panagia tis Asinou). Grids 1, 2 and 3 including GPR data (Staffordshire University, The Cyprus Institute).

In order to cover the maximum area possible, three different grids were established. The largest of these was Grid 1 ( $34.5 \mathrm{~m}$ length $\times 27 \mathrm{~m}$ width). Grid 2 (22.5 m length $\times$ $4 \mathrm{~m}$ width) was a rectangular grid located to the west and Grid 3 (2 m length $\times 15.5 \mathrm{~m}$ width) was located adjacent to the northern wall of the church. Despite the data having been collected separately, several of the anomalies identified were across grids during post-processing and as such these shall be described together.

Several of the anomalies present in the data were modern service trenches (A, B, C and D). A number of metal manhole/drain covers were physically present on the surface across the site, and these presented within the data, as did the trenches containing the buried service pipe connected to them. Contained within these service trenches were either the electricity cables for spotlights or water pipes for external taps (Figure 7). 

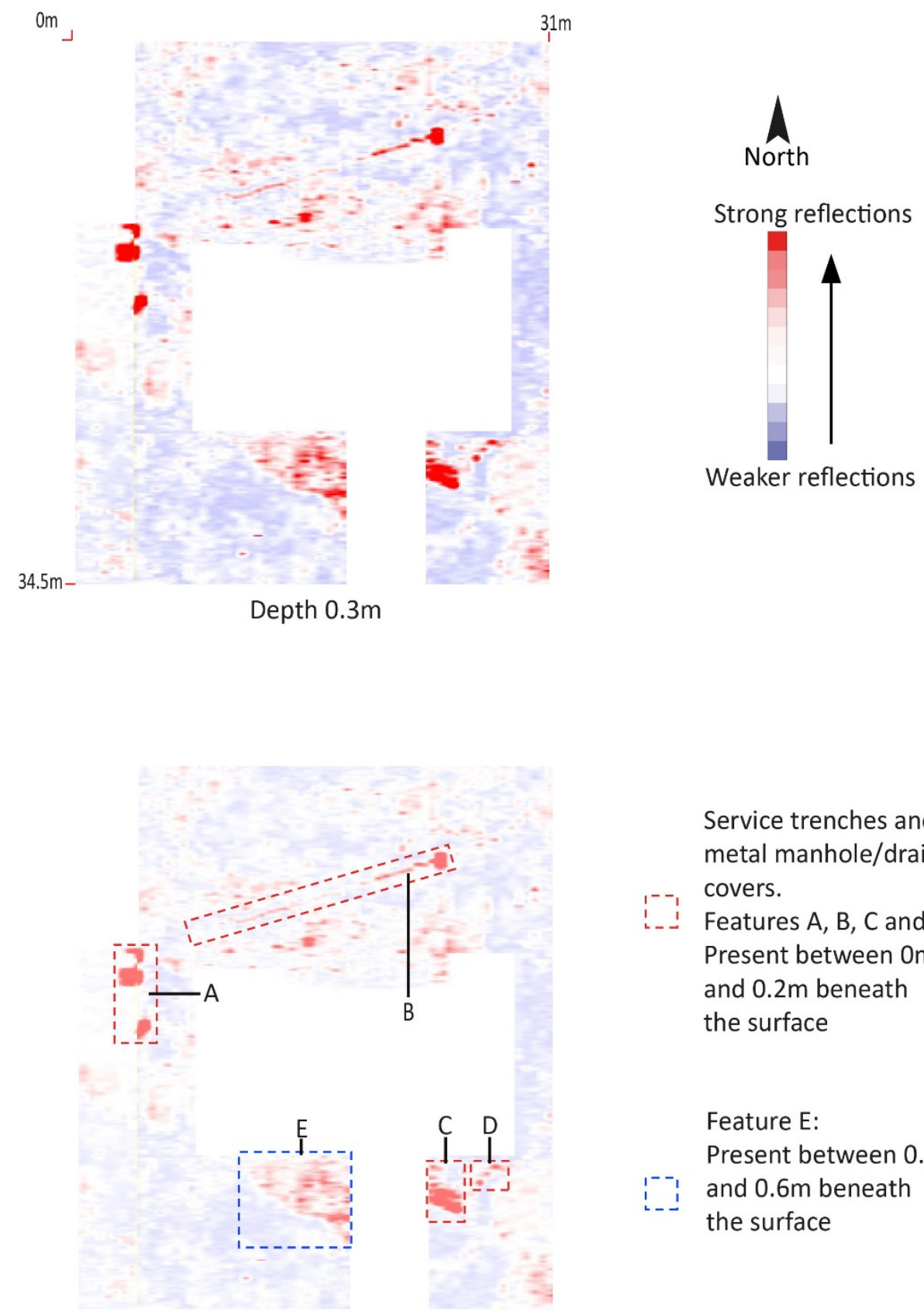

Service trenches and metal manhole/drain covers.

L. Features A, B, C and D: Present between $0 \mathrm{~m}$ and $0.2 \mathrm{~m}$ beneath the surface

Feature E:

Present between $0.1 \mathrm{~m}$

is $0.6 \mathrm{~m}$ beneath the surface

Figure 7. GPR timeslice $(0.3 \mathrm{~m}$ ) from Panagia Phorviotissa (Panagia tis Asinou), Grids 1, 2 and 3 combined. Processed image (top), processed image with annotations (bottom) showing a number of features identified during the survey. (Staffordshire University, The Cyprus Institute).

A service pipe, around $20 \mathrm{~m}$ in length (Feature B) and running south-west to north-east, was present between $0.2 \mathrm{~m}$ and $0.8 \mathrm{~m}$ below ground level. It was located in the northern part of the church enclosure. This feature was linked to a number of access manhole/drain covers at the west of site (Feature A) (Figure 7).

Two further anomalies (Features $C$ and D), identified to the south-east of the church enclosure, were also most likely to have been modern in origin as they were cut from a high level in the stratigraphic sequence. Feature $C$ was a near surface anomaly measuring $1 \mathrm{~m}+$ in length, and present between $0 \mathrm{~m}$ and $0.2 \mathrm{~m}$ beneath the surface. Feature $\mathrm{D}$ was a slightly smaller anomaly present at the same level beneath the surface. These high amplitude signals produced ringing (signals which repeated to a lower depth) in the data. This 
ringing was, however, to a lesser extent than the metal drain covers, and these anomalies cannot therefore entirely be discounted from being structural.

Two large anomalies (Feature E and G; Figures 8 and 9), which were curved in plan, were adjacent to the northern and southern elevations of the church. These anomalies were present between $0.1 \mathrm{~m}$ and $0.7 \mathrm{~m}$ beneath the surface and were between $7 \mathrm{~m}$ and $11 \mathrm{~m}$ in length. These may represent past landscaping of the area, or alternatively, significant wall foundations, rubble or buried surfaces.

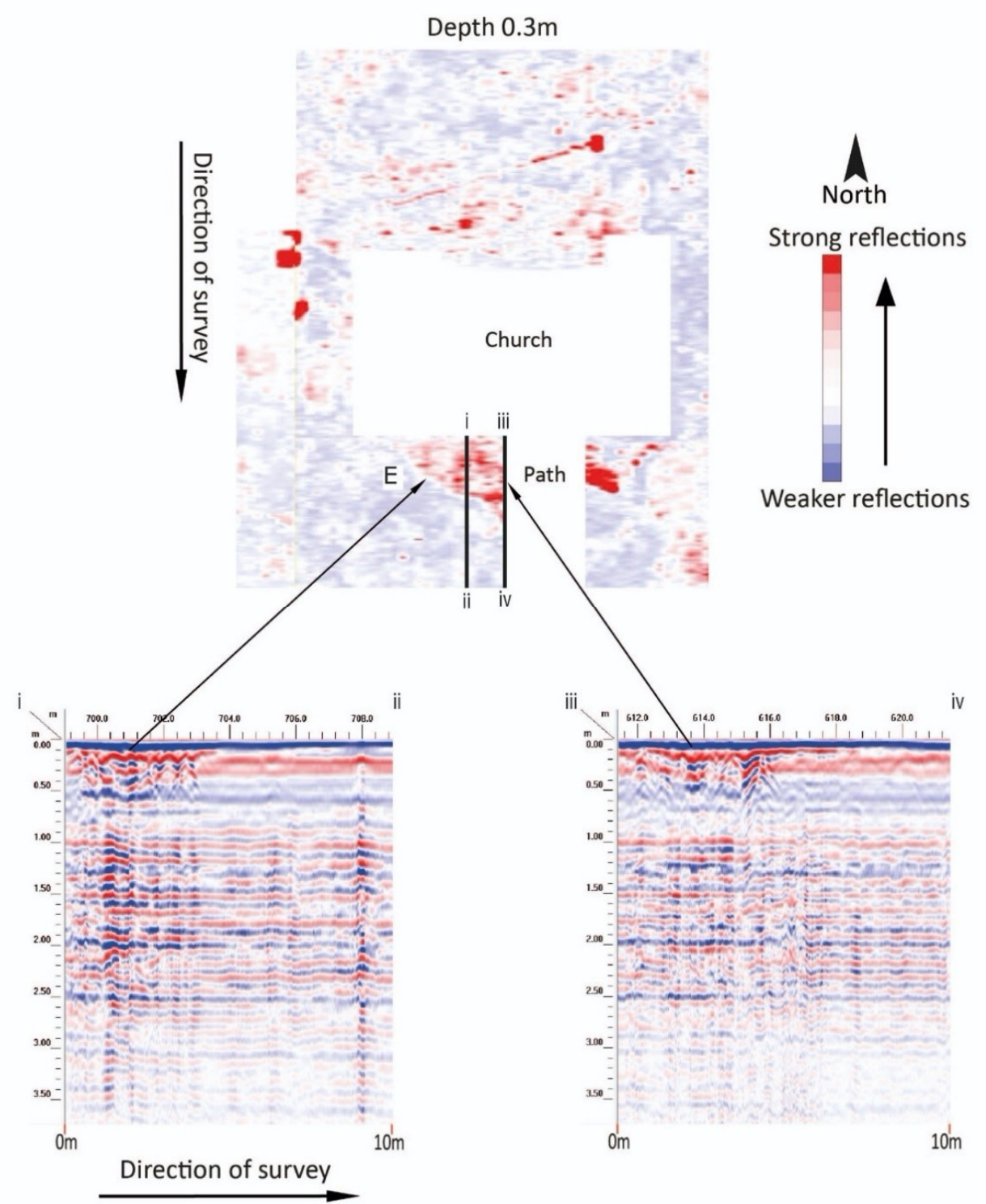

Figure 8. GPR profiles (bottom left, i to ii and right, iii to iv-depth $0.3 \mathrm{~m}$ ) and timeslice (top) from Panagia Phorviotissa (Panagia tis Asinou), Grids 1, 2 and 3 combined, Feature E (Staffordshire University, The Cyprus Institute). 

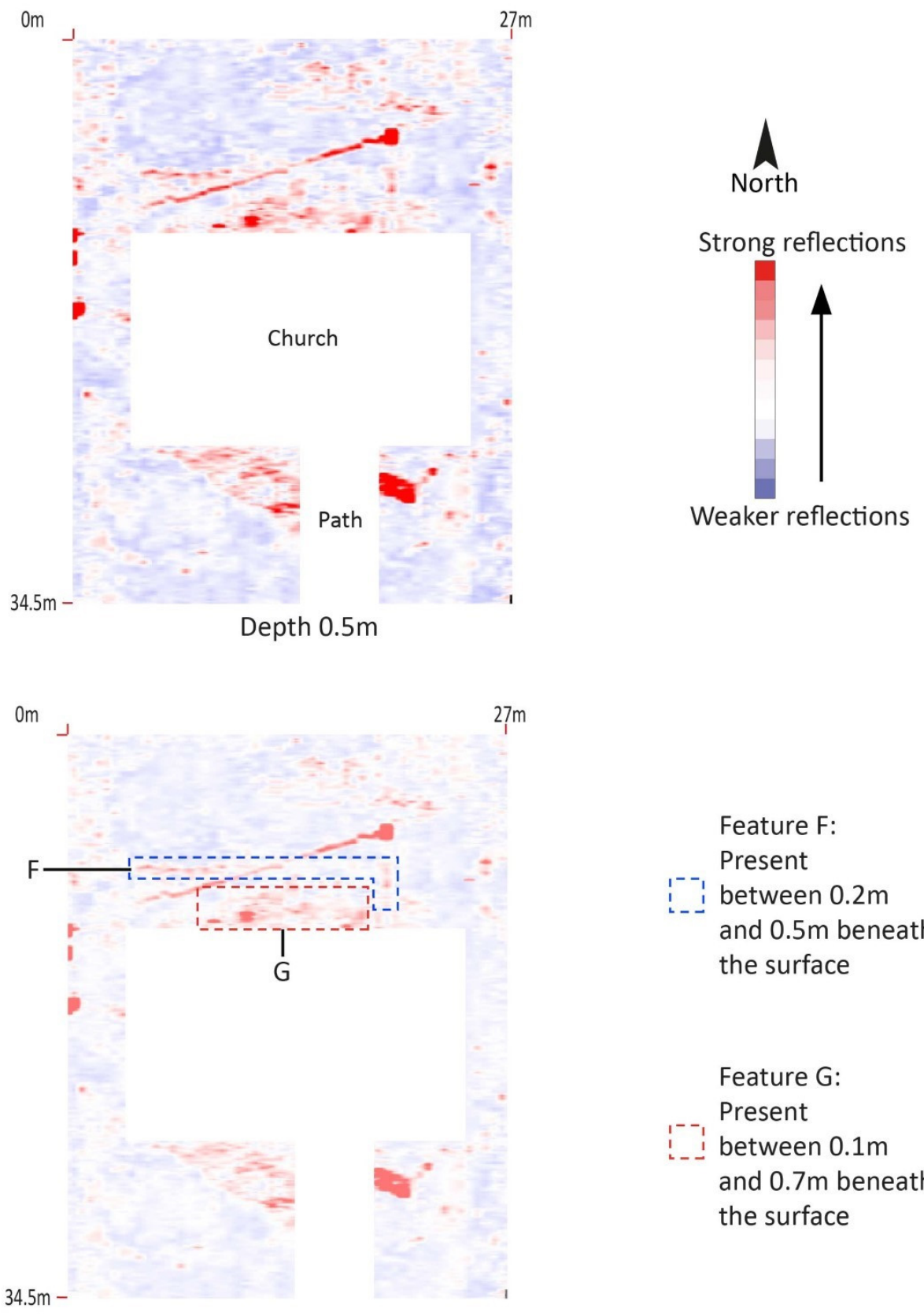

Feature F:

Present

between $0.2 \mathrm{~m}$

and $0.5 \mathrm{~m}$ beneath

the surface

Feature G:

Present

between $0.1 \mathrm{~m}$

and $0.7 \mathrm{~m}$ beneath

the surface

Figure 9. GPR timeslice $(0.5 \mathrm{~m})$ from Panagia Phorviotissa (Panagia tis Asinou), Grid 1. Processed image (top), processed image with annotations (bottom) showing a number of features identified during the survey. (Staffordshire University, The Cyprus Institute).

A linear anomaly parallel to the northern wall of the church (Feature F) was present between $0.2 \mathrm{~m}$ and $0.5 \mathrm{~m}$ beneath the surface. This anomaly was around $15 \mathrm{~m}$ in length and included a return at the eastern end, which was itself around $2.5 \mathrm{~m}$ in length. This feature was present between 0.2 and $0.6 \mathrm{~m}$ beneath the surface. The GPR signal returns gave a different signal response to the other service trench (Feature B), raising the possibility this was a wall foundation (Figure 9).

A significant anomaly (Feature $\mathrm{H}$ ) was present on the north-eastern edge of the survey area. This was around $4.5 \mathrm{~m}$ in length by $1.75 \mathrm{~m}$ in width, although it was probably larger as it continued in an easterly direction outside of the GPR grid. This was present between $0.45 \mathrm{~m}$ and $0.68 \mathrm{~m}$ beneath the surface before disappearing. The feature was regular in plan and was likely to have been a buried structure, once part of the monastery (Figure 10). 


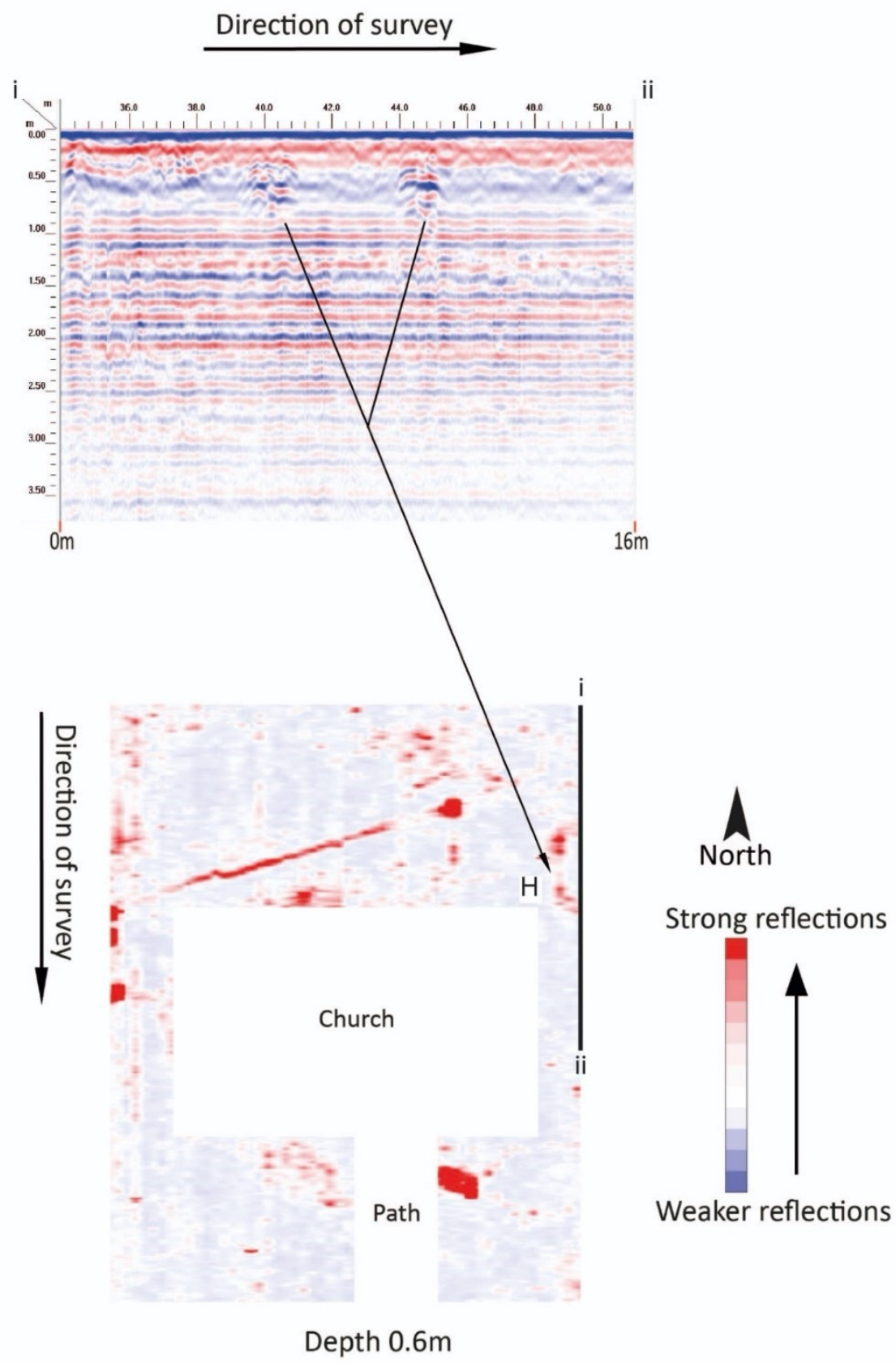

Figure 10. GPR profile (top, i to ii) and timeslice (bottom-depth $0.6 \mathrm{~m}$ ) from Panagia Phorviotissa (Panagia tis Asinou), Grid 1, Feature H (Staffordshire University, The Cyprus Institute).

The GPR survey around the church of the Panagia Phorviotissa provided interesting results that possibly point to building remains related to the now vanished monastery at the site. Features E, F and G are likely to be related to either earlier phases of the church or remains from ancillary structures adjacent or attached to the church building. Furthermore, Feature $\mathrm{H}$ likely relates to the now lost associated monastery structure which was organised around the church. 


\subsection{Site 3: Panagia tou Araka, Lagoudhera, Subsurface Features}

The church of the Panagia tou Araka, located in the outskirts of the village of Lagoudera, preserves celebrated painted decoration from the mid-12th century, possibly associated with the work of famed Byzantine painter Theodore Apsevdis, who is believed to have been trained in Constantinople $[2,22,23]$. The church was built in the late 12th century in the type of the single-aisle church with a dome over the main naos space. A second narthex was added in the 14th century and then rebuilt and extended in the 17th century. An additional wooden roof, covered with flat tiles, was built around this period for the protection of the church from weather conditions and has effectively added a covered Greek $\Pi$ stoa around the building. According to its dedicatory inscription the church was decorated in 1192 with the donations of Leon Afthentis.

In 1735 the Russian monk Barsky visited the monastery, which was inhabited by just three monks [24]. In his drawing he depicted a fully developed monastery with a low enclosure and buildings on the south, west and north sides of the Katholikon church [24].

The monastery continued in use until the first decades of the 19th century. It is presently inhabited by a single caretaker monk. Works to stabilise the precarious slope on the western side of the church were undertaken in 1956 by the Department of Antiquities, at which point a protective wall was constructed [21].

A single large irregular grid was surveyed on the site, the purpose of which was to identify buried structural remains of the former southern range of cells present in Barsky's sketch. The grid ( $26 \mathrm{~m}$ length $\times 25 \mathrm{~m}$ width) was located south of the church upon very dry hard-packed earth. A raised pathway formed of large limestone blocks crossed the grid, the presence of which affected the collection of data and potentially obscured anomalies which may have been present immediately beneath (Figure 11). Several anomalies were identified within this grid, the majority of which were likely to have been structural in origin or resulting from former landscaping on the site, now lost.

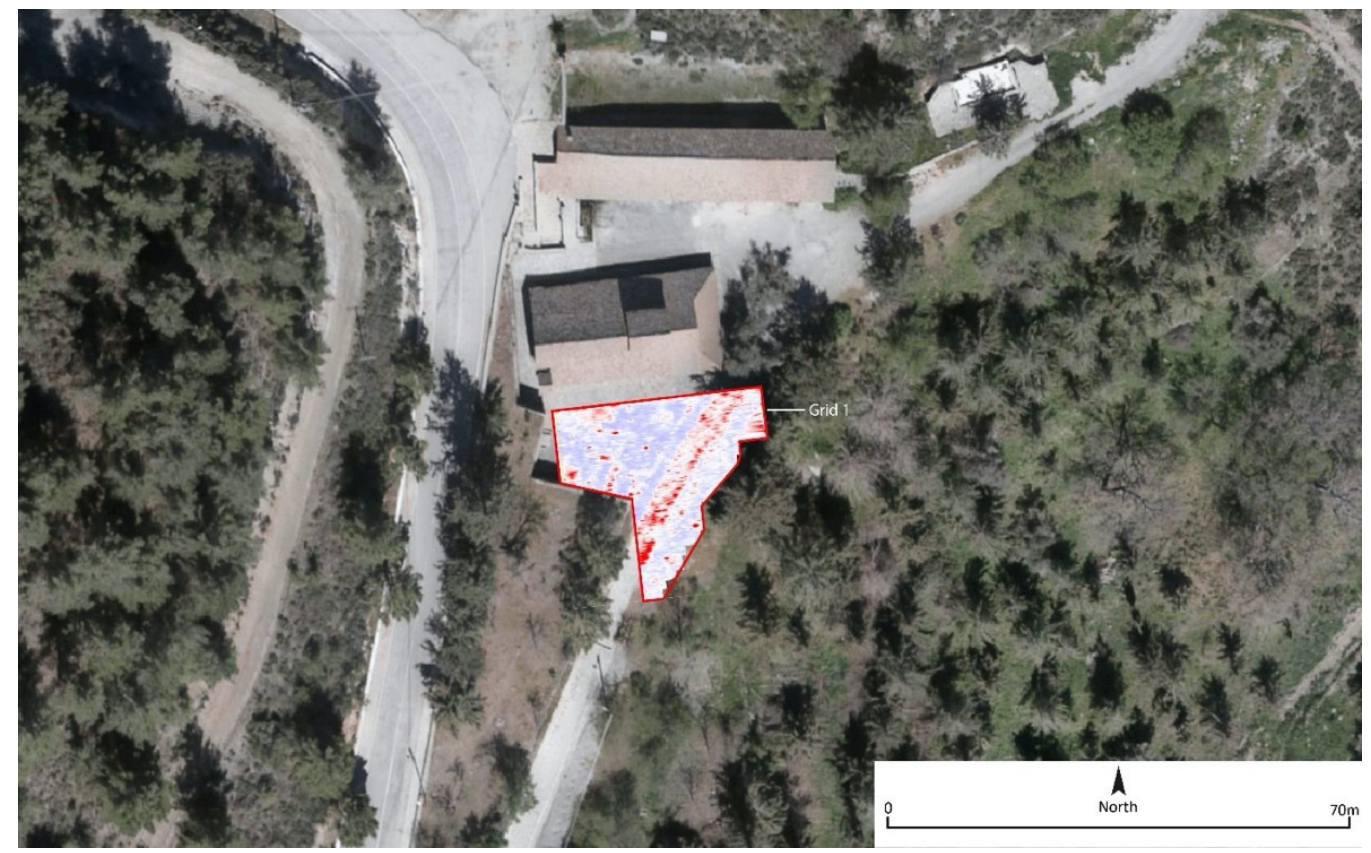

Figure 11. Panagia tou Araka. Grid 1 including GPR data (Staffordshire University, The Cyprus Institute).

The clearest anomaly was the linear feature running from north-east to south-west through the grid. This was the modern stone path. This was a substantial construction, made up of large blocks of stone, each around $30 \mathrm{~cm}$ in depth, and bonded together with a strong mortar (Figures 11 and 12). 


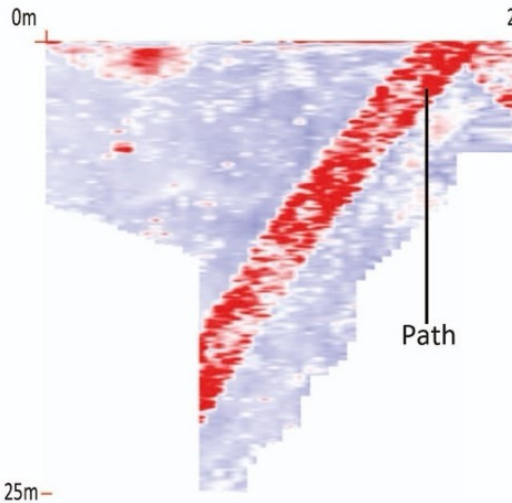

Depth $0.1 \mathrm{~m}$

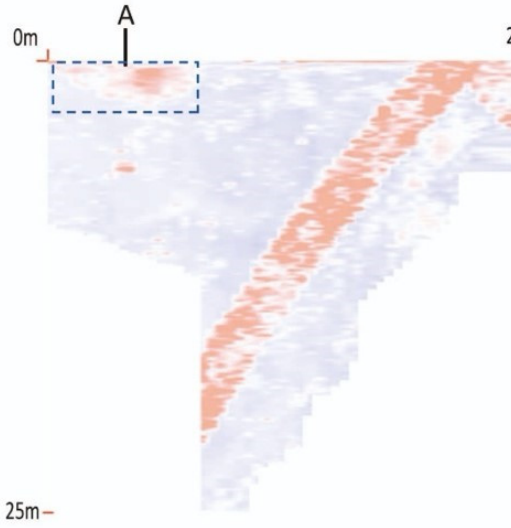

Depth $0.1 \mathrm{~m}$

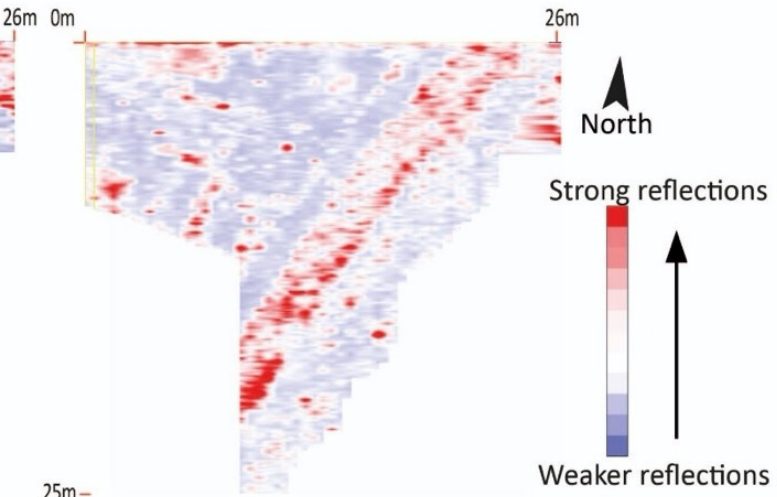

Depth $0.58 m$

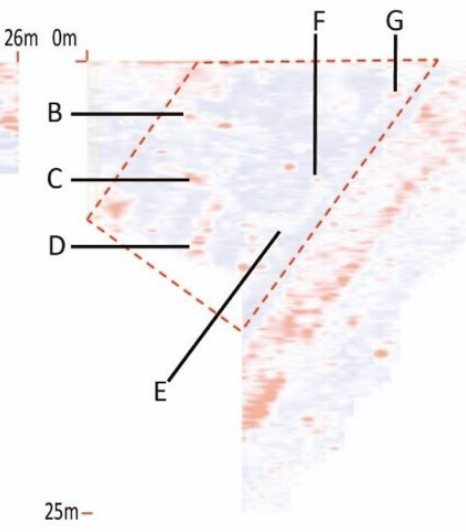

Depth $0.58 \mathrm{~m}$

\author{
$26 \mathrm{~m}$ \\ Feature A: \\ Present \\ .- between $0.1 \mathrm{~m}$ \\ L_ and $1.1 \mathrm{~m}$ \\ beneath \\ the surface \\ Features \\ B, C, D, E, \\ F \& G: \\ -. Present \\ between $0.2 \mathrm{~m}$ \\ and $0.9 \mathrm{~m}$ \\ beneath \\ the surface
}

Figure 12. Two GPR timeslices $(0.1 \mathrm{~m}$ and $0.58 \mathrm{~m})$ from Panagia tou Araka, Grid 1, Features A-G. Processed images (top left $0.1 \mathrm{~m}$ ) and (right $0.58 \mathrm{~m}$ ), processed images with annotations (bottom $0.1 \mathrm{~m}$ and $0.58 \mathrm{~m}$ ) (Staffordshire University, The Cyprus Institute).

A large anomaly, approximately $8 \mathrm{~m}$ by $2.5 \mathrm{~m}$ (Feature A) and identified due to the higher amplitude signal returns, was present in the north-eastern part of the survey area around $0.1 \mathrm{~m}$ and $1.1 \mathrm{~m}$ beneath the surface. This anomaly appeared to be curved in appearance. The depth and shape in plan along with the distinct evidence of a change of material, is suggestive of a large, backfilled pit, perhaps filled with rubble (Figure 11).

Several anomalies covered the area to the north of the modern path (Features B, C, D, E, F and G). These were all present between $0.2 \mathrm{~m}$ and $0.9 \mathrm{~m}$ beneath the surface and are likely to be contemporary with another one. Many of these appear to be connected or part of the same feature, particularly those which were parallel to one another (B and C) or along the same line (E and G). Taken together, Features $C$ and D may also have formed an L-shaped buried feature (Figure 12). Evidence suggests these anomalies were buried walls, structural remains or previous substantial landscaping of the area. This is supported by the pictorial evidence of Barsky which shows buildings once standing on the area south of the main chapel.

The GPR survey located evidence seemingly related to the monastic buildings to the south of the monastic church as depicted in Barsky's drawing. It is difficult to identify specific parts and to relate them to Barsky's sketched structures, but the GPR survey 
provided valuable data for future archaeological work. The rebuilt north wing provides a very useful context for efforts to reimagine the organisation of the Byzantine monastery.

\subsection{Site 4: Panagia tis Podithou, Galata, Subsurface Features}

The church of the Panagia tis Podithou was built in 1502 with the donation of Demetre de Coron and his wife Helen [2-25]. The single-space church is covered by a massive two-side wooden roof which was extended beyond the dimension of the building to cover a Greek $\Pi$ enveloping the building on its north, west and south sides. The interior preserves exquisite wall paintings from the beginning of the 16th century which are considered among the best examples featuring the influence of Italian Renaissance art. The church was part of a monastery, described by the Russian monk Barsky, who in 1734 described that the monks present at the site were housed in a two-story building built from mud-brick [24]. The building survived until the 1950s and is preserved in old photographs. The monastery was abandoned in the early decades of the 19th century, most probably following the Greek revolution of 1821 and its terrible aftermath for the Greeks of Cyprus. As a result of this development, the monastery's buildings were reused later in the 19th century as a school (Figure 13).

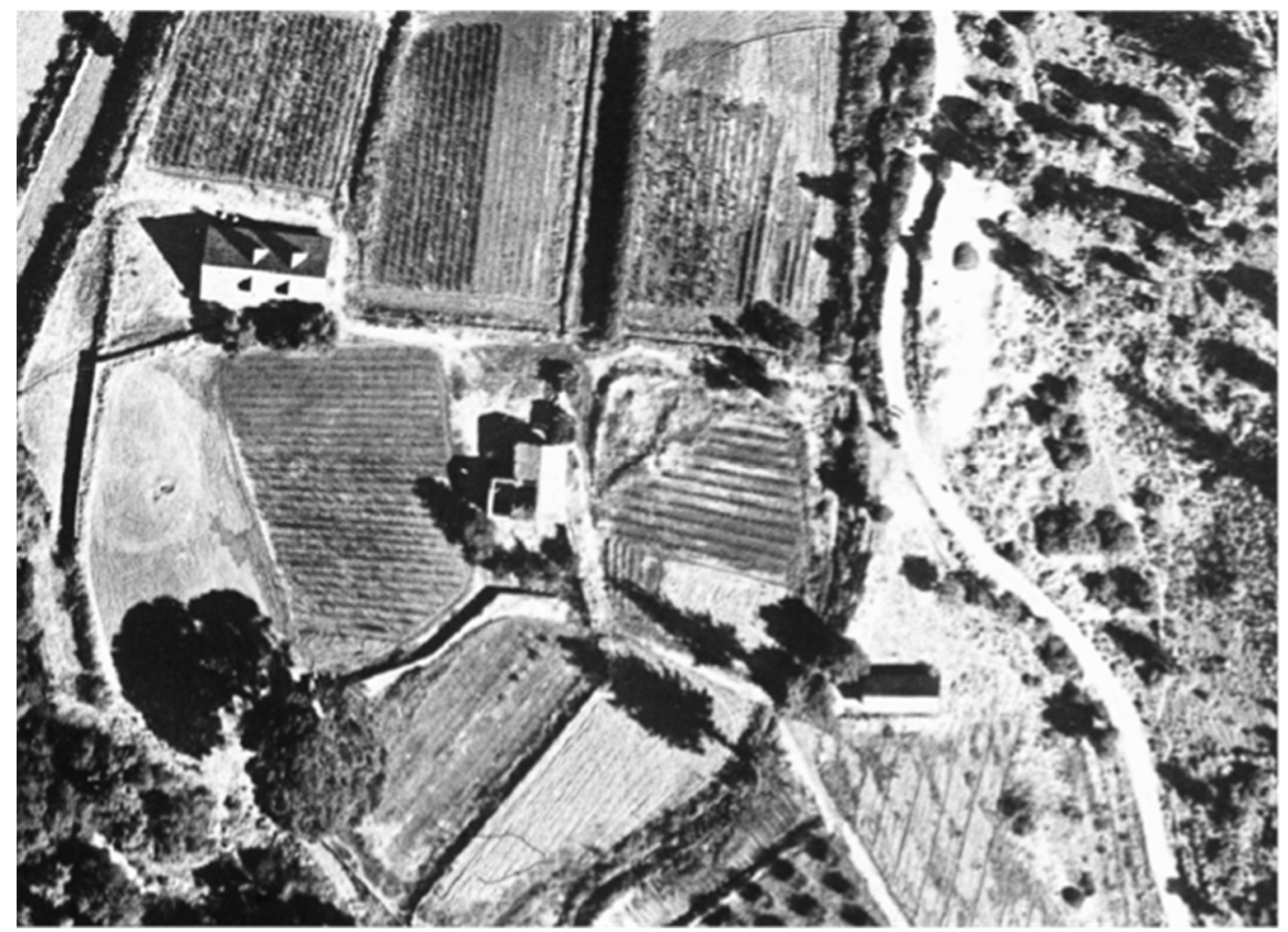

Figure 13. Panagia tis Podithou 1963, aerial image of the church and the monastic cells (Department of Land and Survey of Cyprus).

Three grids were undertaken on the site (two of which are mentioned here), the purpose of these were to identify the now lost monastic cells identified in the historic imagery and documentary evidence. The grids (Grid 1-64 m length $\times 35 \mathrm{~m}$ width, Grid $2-25 \mathrm{~m}$ length $\times 19 \mathrm{~m}$ width and Grid 3-26 m length $\times 25 \mathrm{~m}$ width) were located to the south and south-east of the church upon loose, very dry hard-packed earth with lots of rocky debris. The ground has recently been used for agriculture, which had churned up the top layers. Larger stones were visible around the outside of the fields, probably removed during cultivation practices. The field containing Grid 2 was terraced above the field containing Grid 1/3 and there was a stone terrace separating the two. Within this terrace there was significant evidence of building rubble. The results of Grid 1 are not recorded here as these are superseded by Grid 3 (Figure 14). 


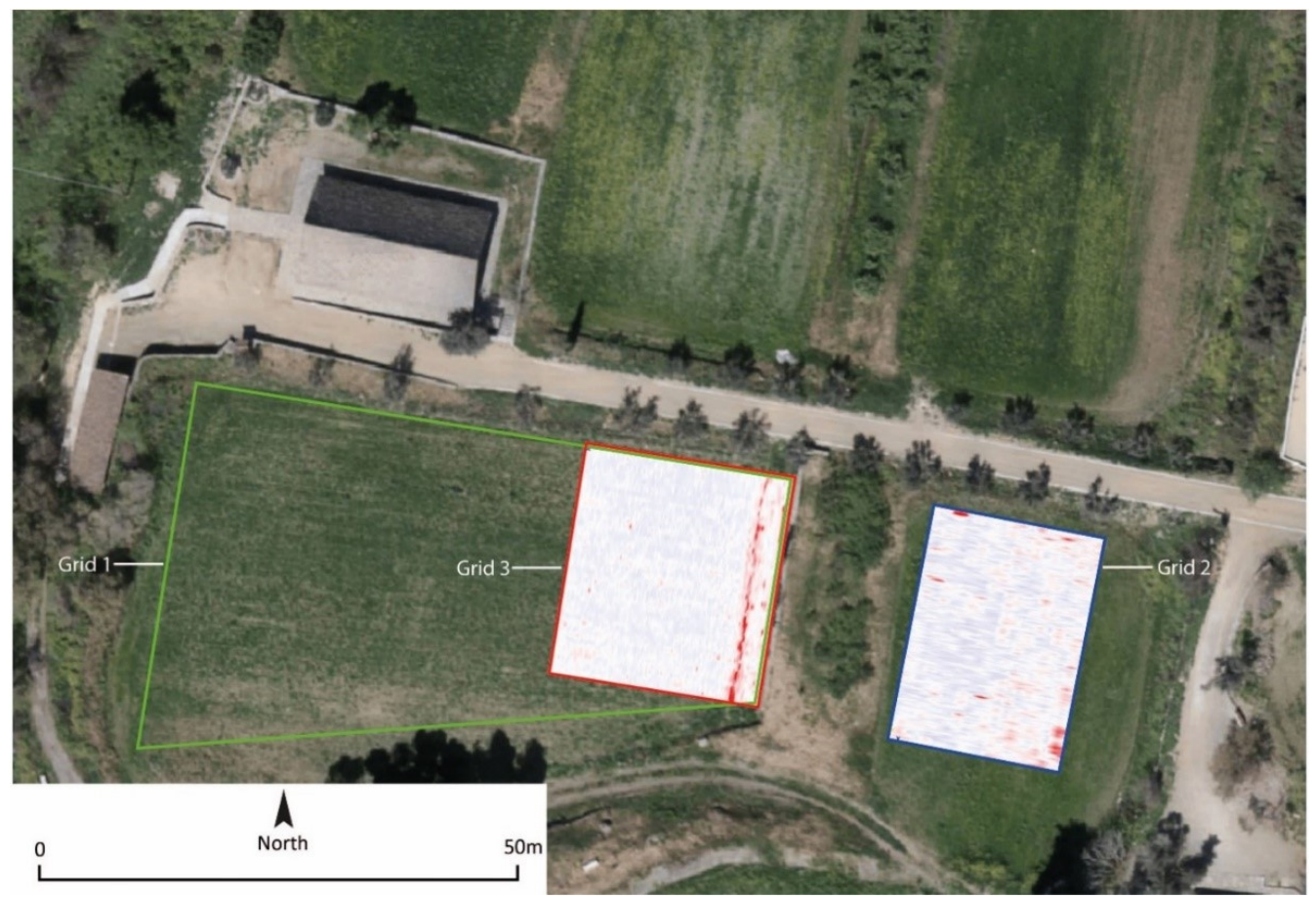

Figure 14. Panagia tis Podithou. Grids 2 and 3, including GPR data (Staffordshire University, The Cyprus Institute).

The data collected from Grid 2 did not reveal any significant buried features or evidence of buried structures. Several high amplitude reflections present across the area were likely to have been buried metal as these created significant reflections within the data. A single anomaly (Feature C) was identified at the south-eastern corner of the grid. This was approximately $2 \mathrm{~m}$ in length extending to around $3 \mathrm{~m}$ and was identified between $0 \mathrm{~m}$ and $0.3 \mathrm{~m}$ beneath the surface. This feature was most likely a shallow pit (Figure 15).

Two linear anomalies were identified at the eastern end of Grid 3. Both were present between $0.1 \mathrm{~m}$ and $0.6 \mathrm{~m}$ beneath the surface and ran north-south. The first anomaly (Feature A) was observable on the ground as a raised bank of material. This feature, which ran the width of the grid $(25 \mathrm{~m})$, may have been present as a result of a specific agricultural practice or a buried service trench. The second anomaly (Feature B) was identified close to the terrace wall at the eastern end of the trench. This was approximately $15 \mathrm{~m}$ in length and may represent shallow foundations compatible with the west edge of the monastic complex (Figures 15 and 16).

The eastern end of Grid 1/3 was expected to be the area likely to contain foundation evidence for the two-story monastic cells, which formerly stood here prior to demolition in the mid-20th century. The limited amount of surviving evidence confirms that the survival of structural material is limited to the area between the two grid areas (a large amount of worked stone was present here). GPR and topographic survey suggests that the majority of the foundations appear to have been removed from the field, probably as they were brought to the surface through invasive cultivation. Many large, worked stones were present around the field edge. 

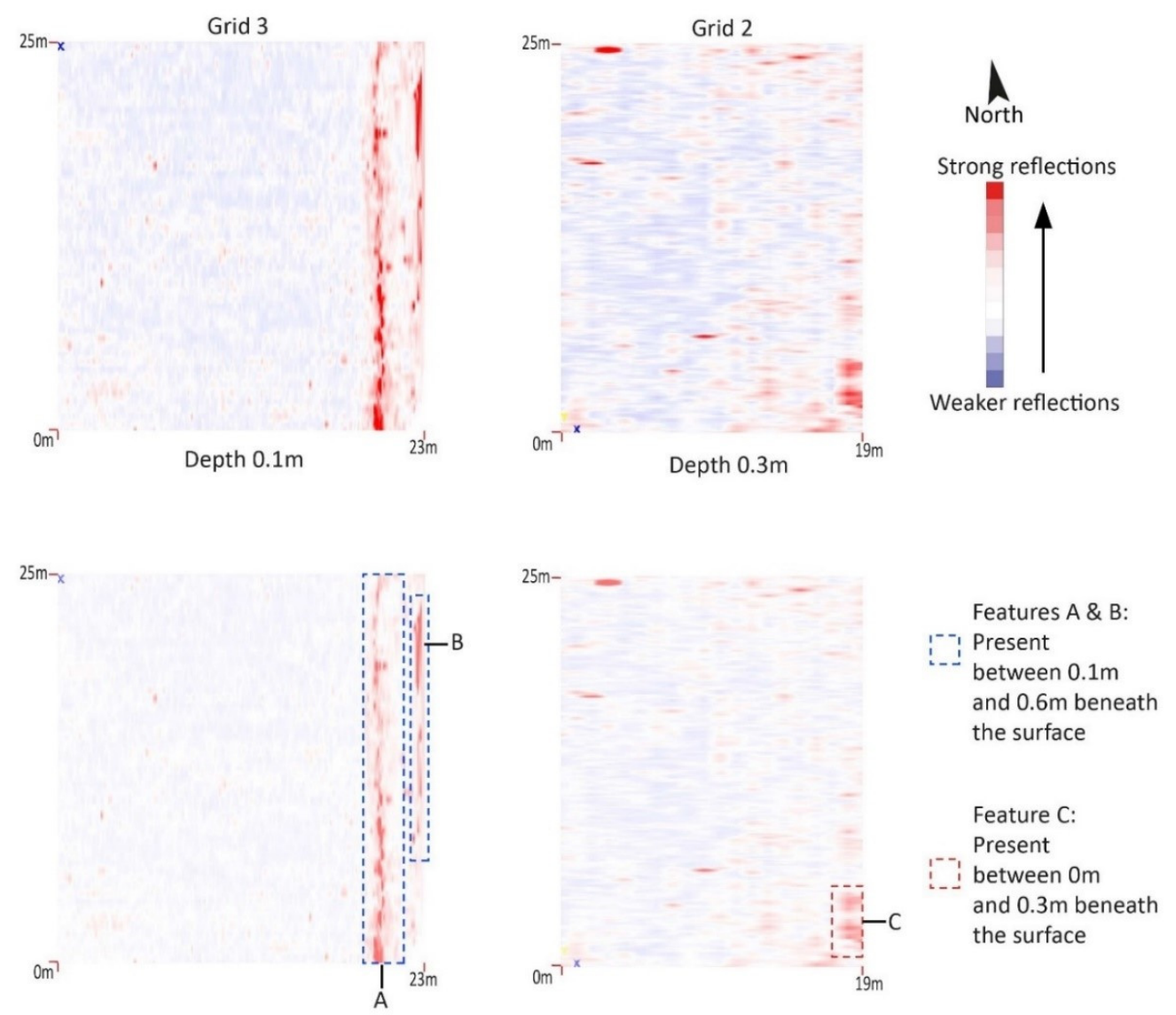

Figure 15. GPR timeslice $(0.1 \mathrm{~m}$ and $0.3 \mathrm{~m})$ from Panagia tis Podithou, Grids 2 (right) and 3 (left). Processed images (top left and right), processed images with annotations (bottom left and right) showing features identified during the survey. (Staffordshire University, The Cyprus Institute).

No significant evidence from the earlier monastery was identified through the application of GPR. It seems that the use of the land around the church for farming erased or disturbed any remains, thus rendering them undetectable. The existence of photographic evidence of the two-floor building housing the cells of the monks and other monastic needs offers an invaluable context for the old monastery. Moreover, Feature B is worth exploring in the future as is the terrace between the two grids, as these may be related to the enclosure of the monastery or a different monastic structure. Archaeological excavation could certainly enhance our knowledge of the site and reveal further information of its architectural form and usage. 


\section{Grid 3}

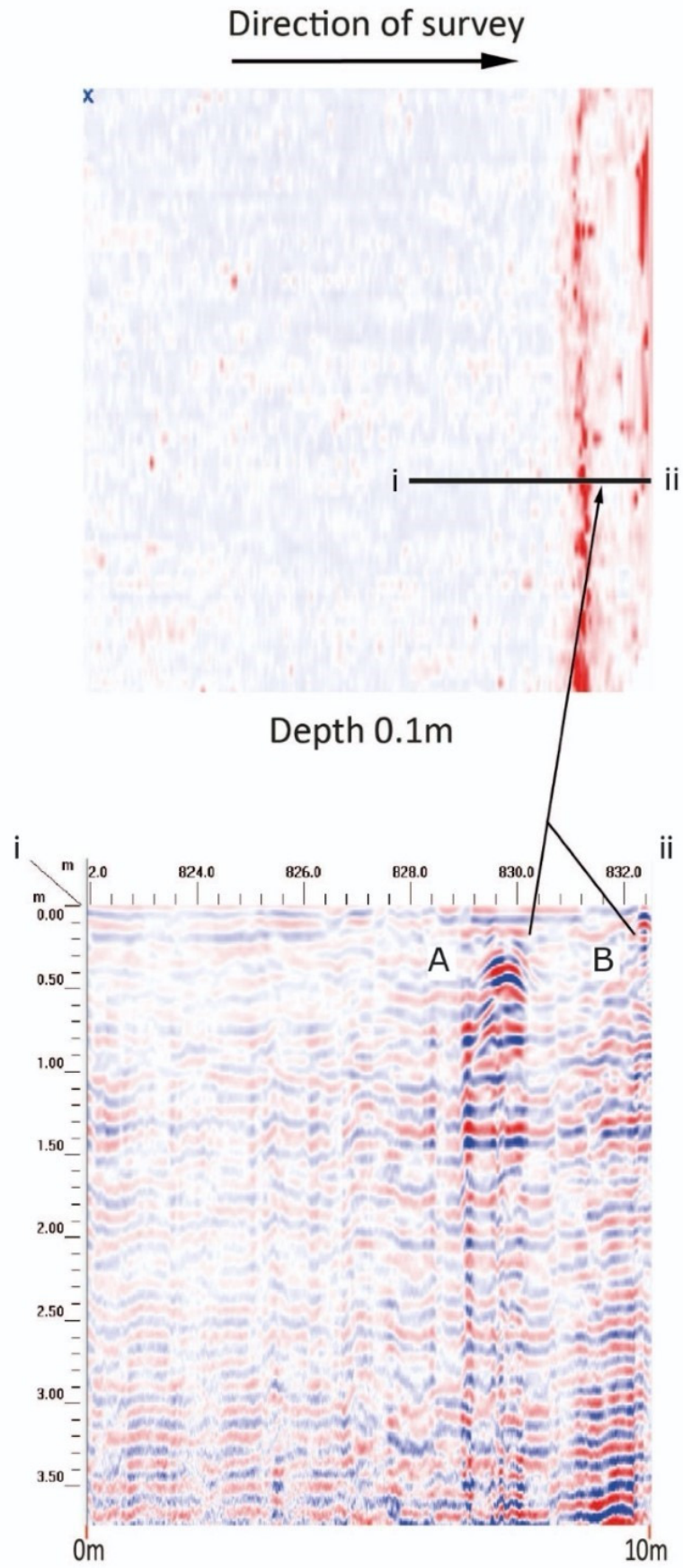

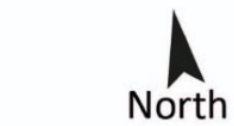

Strong reflections

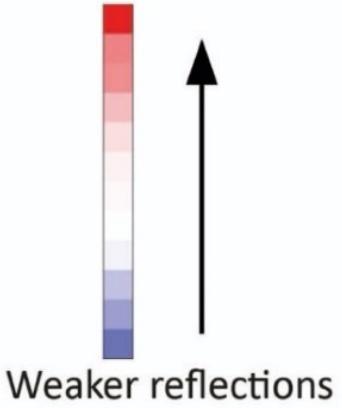

Figure 16. GPR profile (bottom, i to ii) and timeslice (top, depth $0.1 \mathrm{~m}$ ) from Panagia tis Podithou Grid 3, Features A and B (Staffordshire University, The Cyprus Institute).

\subsection{Site 5: Stavros tou Agiasmati, Platanistasa, Subsurface Features}

The single-space stone building of the church of the Stavros tou Agiasmati is covered by an impressive two-sided wooden roof which provides protection and shade to visitors and pilgrims to this picturesque, forested location close to the village of Platanistasa [2-26].

Based on the inscription located above the exterior north wall, the church was built thanks to the donation of a priest and his wife, namely Petros Peratis and Pepani. The couple, offering a model of the church to Jesus, is depicted on a fresco decorating the south 
exterior wall. Although the date of church's erection is unknown, it is commonly accepted that the paintings were completed between the years 1494 and 1500 .

According to an inscription on the exterior north wall above the entrance to the church, the building was erected with the donation of a priest named Petros Peratis and his wife Pepani. Both of them are depicted on a wall-painting on the south exterior wall, offering a model of the church to Jesus with the mediation of the Virgin. The year of the church's erection is not known, but it is generally accepted that its exceptional decoration was completed in 1494 or around 1500. This is probably the date of the church's construction. A valuable record of the monastery at the site is provided in the diary of the Russian monk Barsky who came to Agiasmati in 1935. Some of the historical change to the site can be determined through the writings of the Russian Monk Barsky [24]. The description of his visit in 1735 indicates that the monastery was almost abandoned at the time thus providing a rough timeframe for the decline of the monastic complex. Barsky mentioned that only one monk was present and that only the ruins of the monastic cells survived to the south of the church. Due to the restrictive nature of the topography and the presence of several significant obstacles, it was only possible to undertake two small surveys at this site (Figure 17).

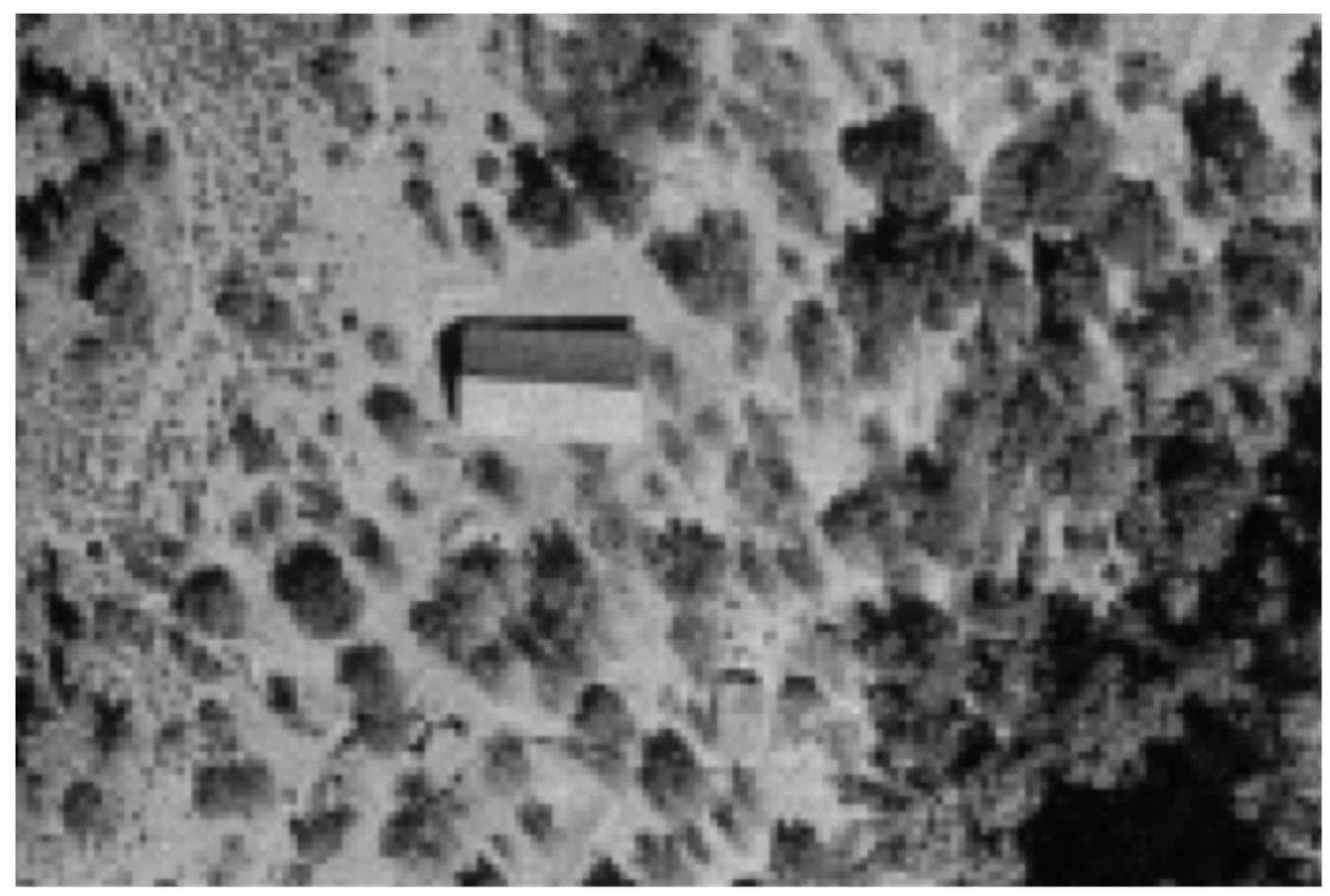

Figure 17. Stavros tou Agiasmati (Platanistasa), 1963 aerial image (Department of Land and Survey of Cyprus).

A square grid was undertaken to the south of the church (Grid 1, 11 $\mathrm{m} \times 10 \mathrm{~m}$ ) and a rectangular grid was undertaken to the north of the church (Grid 2, 25 m $\times 19 \mathrm{~m}$ ). Both were positioned to identify potential buried structural remains or burials within the monastic complex and both were located upon very dry hard-packed earth (Figure 18).

A single linear anomaly (Feature A) was identified running north-south through the centre of Grid 1. This was present around $0.3 \mathrm{~m}$ and $0.5 \mathrm{~m}$ below ground level and was likely to be a service trench (electricity) leading to the church. Additional high signal returns present across the survey area were indicative of buried metal (Figure 19). 


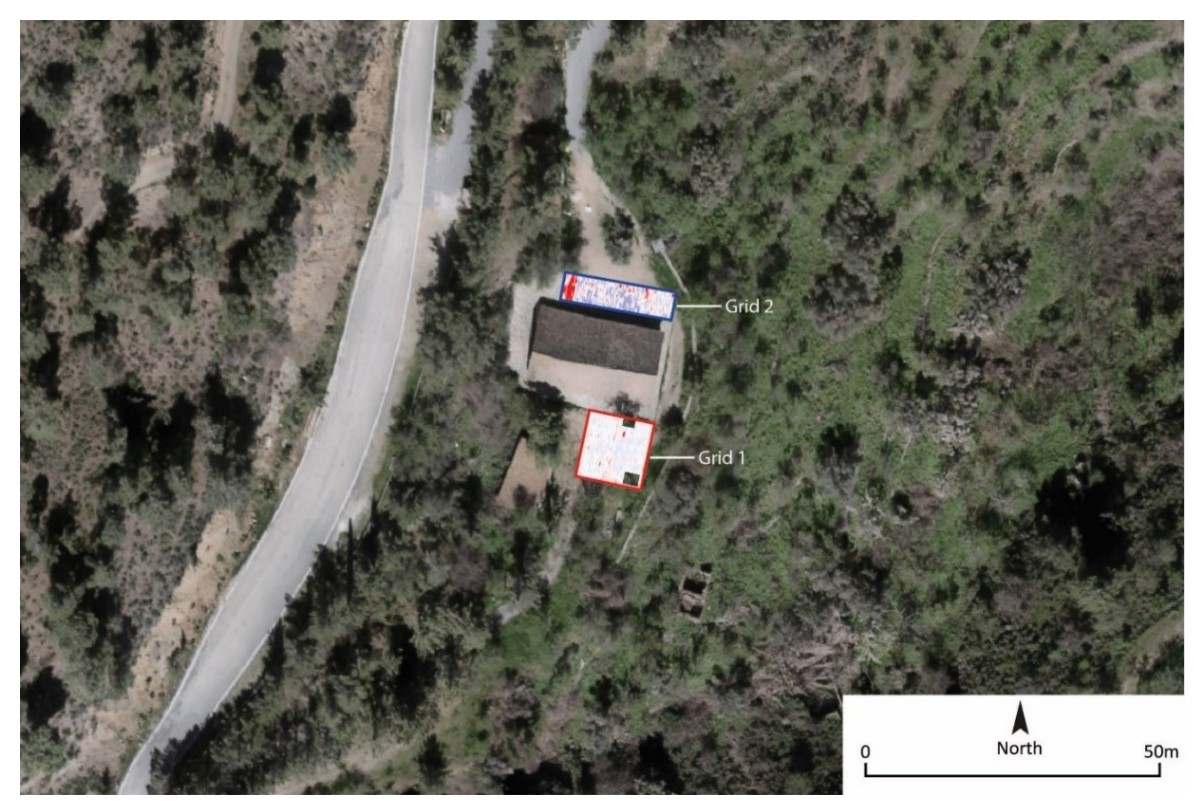

Figure 18. Stavros tou Agiasmati, Grids 1 and 2, including GPR data (Staffordshire University, The Cyprus Institute).
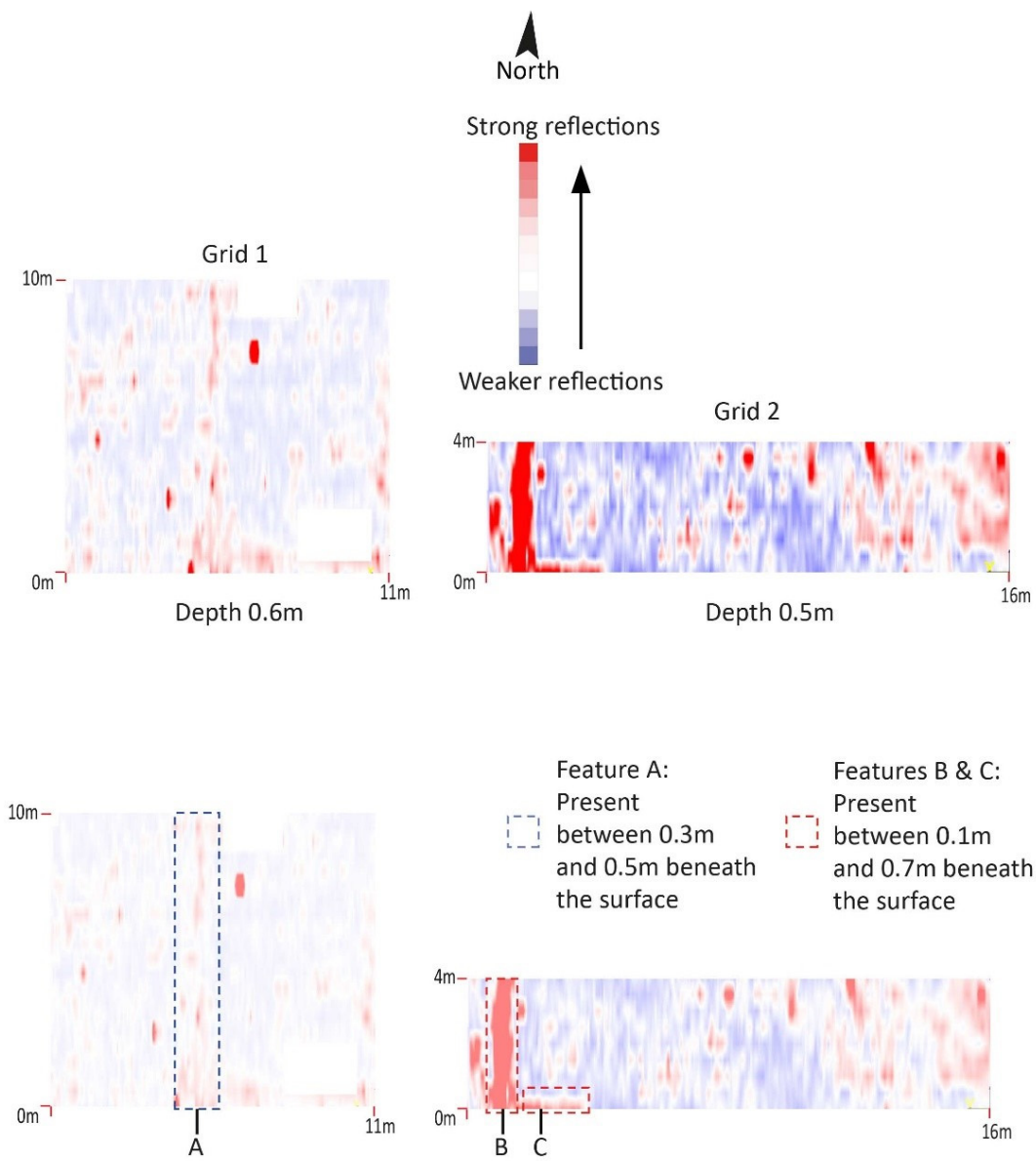

Figure 19. GPR timeslices ( $0.6 \mathrm{~m}$ and $0.5 \mathrm{~m})$ from Stavros tou Agiasmati, Grid 1 (left) and Grid 2 (right). Processed images (top left and right), processed images with annotations (bottom left and right) showing features identified during the survey. (Staffordshire University, The Cyprus Institute). 
Two anomalies (Features B and C) were identified towards the western end of Grid 2. Both were present between $0.1 \mathrm{~m}$ and $0.7 \mathrm{~m}$ beneath the surface. Feature $B$ ran in a north-south direction and may have been a service trench containing a non-metallic pipe. Feature $C$ was of most interest as it contained a distinct change of material suggesting a backfilled foundation trench or surviving structural remains (Figure 20).

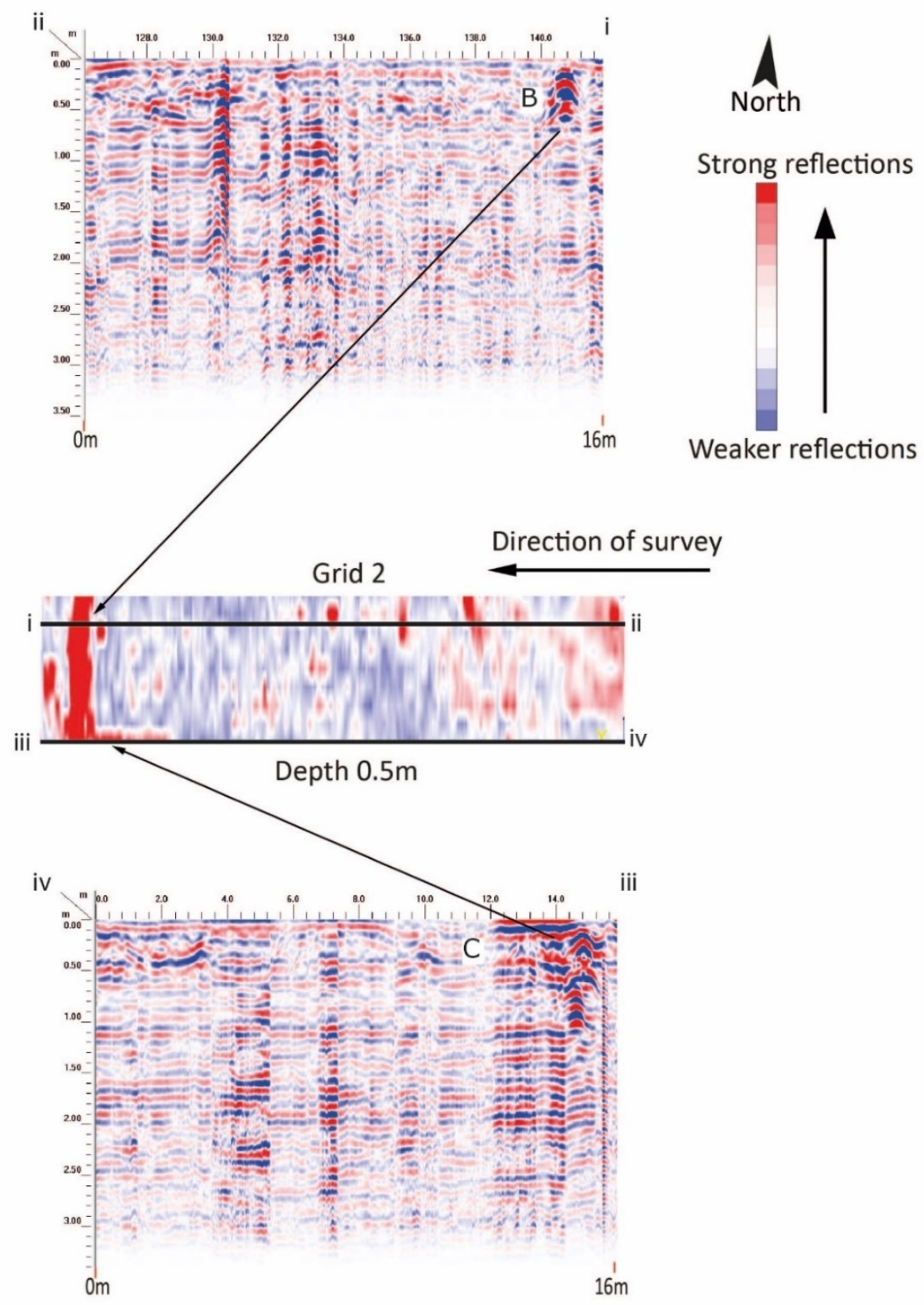

Figure 20. GPR profiles (top, i to ii and bottom iii to iv, depth $0.58 \mathrm{~m}$ ) and timeslice (middle) from Stavros tou Agiasmati Features B and C (Staffordshire University, The Cyprus Institute).

Unfortunately, the GPR survey around the standing church of the Stavros tou Agiasmati did not offer conclusive evidence to support the interpretation of how the now vanished monastery was organised. In addition to the description of Barsky which did locate the cell-wing of the monastic complex south of the church, the data collected do not provide any evidence to physically locate them. Grid 2 offered possible evidence for a 
foundation trench or remains immediately to the north of the present church. These could be related to structures annexed to the main church of what is expected to have been a monastery which was comparatively small in size. However, excavation would be needed to confirm this.

\section{Conclusions}

The research undertaken on these five sites in the Troodos Mountains has enhanced both our archaeological knowledge of these sites and the selection of non-invasive methodological techniques which can be employed within the region. A number of surface and subsurface features were observed during the post-processing of the GPR data and the surveys provided new insights into the preservation and destructive processes that have occurred at each site in the decades since the construction of each monastic complex. In general, the existence of physical remains was largely dependent on the methods and practices of deconstruction and demolition that the former monastic buildings or structures were subjected to. Past building techniques and materials also played a significant role in the preservation of physical remains.

The use of a lower frequency antenna (350 MHz) and larger sampling concentration for the GPR survey was successfully employed in this study to identify surviving structural archaeological remains at each of these sites. Anomalies were identified at each of the surveyed sites and it is clear that some of these deserve further investigation to clarify their existence and significance.

The most noteworthy geophysical results came from two of the five monastery sites surveyed, specifically the Panagia Phorviotissa (Panagia tis Asinou) near Nikitari and the Panagia tou Araka near Lagoudera. At Panagia Phorviotissa (Panagia tis Asinou), three features are likely to represent now buried structural features directly associated with the current church structure. An anomaly, identified on the edge of the grid, is likely to be a lost monastery structure associated with the monastery complex. At Panagia tou Araka, the anomalies identified in the data possibly represent buried walls, structural remains and/or previous substantial landscaping of the area. Targeted confirmatory excavations are recommended at these sites as buried structural remains are highly likely to exist. Possible buried remains were also identified at three other sites (Agios Nikolaos tis Stegis, Kakopetria, Panagia tis Podithou, Galata and Stavros tou Agiasmati, Platanistasa), although these results were difficult to characterise and were infrequent in occurrence. Based on the GPR results, these are sites are considered to be of lower archaeological potential.

As described above, the collection of data in the Troodos Mountains was hindered by the geology which was clay-rich with substantial rubble inclusions, consequently making interpretation difficult. This was particularly true at the last three sites mentioned above and for the identification of any subtle buried remains such as clandestine burials, which may remain across all five locations. Therefore, the existence of such features as well as further buried remains cannot be ruled out without more invasive works. Overall, whilst the use of GPR has led to the identification of locations that are highly likely to contain buried structural remains, this research has further confirmed that this method should be utilised as part of a suite of methods capable of archaeological detection.

Author Contributions: Conceptualization, D.A., K.S.C., W.L.M., C.S.C. and N.B.; methodology, K.S.C., W.L.M., C.S.C., D.A. and M.F.; software, W.L.M., K.S.C. and C.S.C., validation, K.S.C., W.L.M., C.S.C. and M.F.; formal analysis, K.S.C., W.L.M. and C.S.C., investigation, W.L.M., D.A. and M.F.; resources, D.A.; data curation, K.S.C., W.L.M., C.S.C., D.A. and M.F.; writing-original draft preparation, D.A., W.L.M. and N.B.; writing-review and editing, D.A., K.S.C., W.L.M., C.S.C. and N.B.; visualization, W.L.M., K.S.C., C.S.C. and D.A.; supervision, D.A.; project administration, D.A.; funding acquisition, D.A. All authors have read and agreed to the published version of the manuscript.

Funding: This research was funded by the Project EXCELLENCE/0918/0144, co-financed by the European Regional Development Fund and the Republic of Cyprus through the Research and Innovation Foundation. 


\begin{abstract}
Acknowledgments: The authors wish to thank the Department of Antiquities of Cyprus, and in particular its director Marina Solomidou-Ieronymidou, for the authorisation to conduct the field work and publish its preliminary results (File 14.03.001.05/4). Additionally, the IH-AT team acknowledges the support of the Bishopric of Morphou and the Archbishopric of Cyprus for the support provided on site during the data collection. A special mention goes to Alex Haycock and Harriette Copley of Staffordshire University for the GPR data collection survey, as well as, to Despina Papacharalambous of the Cyprus Institute for contributing to research on the history and the art of the Troodos churches.
\end{abstract}

Conflicts of Interest: The authors declare no conflict of interest.

\title{
References
}

1. UNESCO 2021. Available online: https:/ /whc.unesco.org/en/list/351/ (accessed on 30 August 2021).

2. Stylianou, A.; Stylianou, J. The Painted Churches of Cyprus, Treasures of Byzantine Art; A.G. Leventis Foundation: London, UK, 1997; pp. 312-320.

3. Hein, E.; Jakovljevic, A.; Kleidt, B. Cyprus: Byzantine Churches and Monasteries, Mosaics and Frescoes; Melina: Ratingen, Germany, 1998.

4. Ćurčić, S. Middle Byzantine Architecture on Cyprus: Provincial or Regional? Bank of Cyprus Cultural Foundation: Nicosia, Cyprus, 2000.

5. Curčić, S.; Panagia Arakiotissa Church, Lagoudera; Bakirtzis, C.; Hadjichristodoulou, C. (Eds.) The Church of Panagia tou Arakos; Leventis Foundation and Bank of Cyprus Cultural Foundation Nicosia: Nicosia, Cyprus, 2018; pp. 19-26.

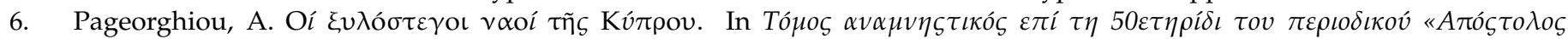

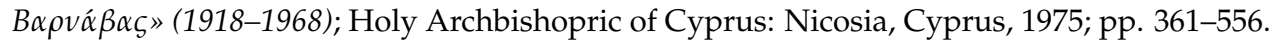

7. Grasmueck, M.; Weger, R.; Horstmeyer, H. Full-resolution 3D GPR imaging. Geographycs 2005, 70, 12-26. [CrossRef]

8. Conyers, L.B. Ground-Penetrating Radar for Archaeology. In Geophysical Methods for Archaeology No. 4, 3rd ed.; AltaMira Press: Lanham, MD, USA, 2015; Volume 23, pp. 71-72. [CrossRef]

9. Utsi, E.C. Ground Penetrating Radar: Theory and Practice; Butterworth-Heinemann: Oxford, UK, 2017.

10. Urban, T.M.; Leon, J.F.; Manning, S.W.; Fisher, K.D. High Resolution GPR Mapping of Late Bronze Age Architecture at KalavasosAyios Dhimitrios, Cyprus. J. Appl. Geophys. 2014, 107, 129-136. [CrossRef]

11. Lowe, K.M.; Fogel, A.; Sneddon, A. Archaeological Geophysical Survey of a Prehistoric Bronze Age Site in Cyprus (Alambra Mouttes)-Applications and Limitations. Archaeol. Anthr. Sci. 2017, 10, 1971-1989. [CrossRef]

12. Manning, S.W.; Andreou, G.M.; Fisher, K.D.; Gerard-Little, P.A.; Kearns, C.M.; Leon, J.F.; Sewell, D.A.; Urban, T.M. Becoming Urban: Investigating the Anatomy of the Maroni Late Bronze Age Complex. J. Mediterr. Archaeol. 2014, 27, 3-32. [CrossRef]

13. Republic of Cyprus, Ministry of Agriculture, Meteorological Service. 2020. Available online: http://www.moa.gov.cy/moa/dm/dm. nsf /All/F5466970E86E9AF1C225864200312453/\$file/SEECOF_Nov_Dec_2020_Jan_2021_UK.pdf (accessed on 30 August 2021).

14. Urban, T.M.; Leon, J.F.; Manning, S.W.; Fisher, K.D.; Kearns, C.M.; Gerard-Little, P.A. Ground-Penetrating Radar Investigations at Kalvasos-Ayios Dhimitrios Offer a New Look at Late Bronze Age Cyprus. Antiq. J. 2013, 87, 338.

15. Rogers, M.; Leon, J.F.; Fisher, K.D.; Manning, S.W.; Sewell, D. Comparing Similar Ground-penetrating Radar Surveys Under Different Moisture Conditions at Kalavasos-Ayios Dhimitrios, Cyprus. Archaeol. Prospect. 2012, 19, 297-305. [CrossRef]

16. Hadjichristodoulou, C.; Myrianthefs, D. The Church of Our Lady of Asinou; Bank of Cyprus Cultural Foundation: Nicosia, Cyprus, 2002.

17. Geophysical Survey Systems, Inc. SIR®4000 Manual; Geophysical Survey Systems, Inc.: Nashua, NH, USA, $2014-2017$.

18. Chartered Institute for Archaeologists. Standards and Guidance for Archaeological Geophysical Survey. 2014. Available online: https:/ / www.archaeologists.net/sites/default/files/CIfAS\&GGeophysics_1.pdf (accessed on 30 August 2021).

19. IH-AT. Art-Historical State of the Art Report Regarding the 10 UNESCO Churches in the Troodos Area, Internal Project Report. 2020; unpublished.

20. Parani, M.G. Asinou across Time. Studies in the Architecture and Murals of the Panagia Phorbiotissa, Cyprus; Weyl-Carr, A., Nicolaïdès, A., Eds.; Dumbarton Oaks Studies: Washington, DC, USA, 2013.

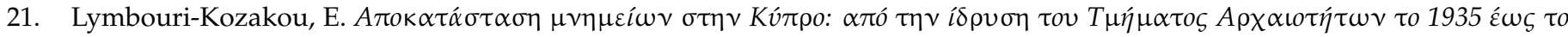
2005; Department of Antiquities: Nicosia, Cyprus, 2018.

22. Nicolaïdès, A. L'eglise de la Panagia Arakiotissa a Lagoudera, Chypre: Etude Iconographique des Fresques de 1192. Dumbart. Oaks Pap. 1996, 50, 1. [CrossRef]

23. Anastasios, G. The Church of Panagia tou Arakos; Papageorghiou, A., Bakirtzis, C., Hadjichristodoulou, C., Eds.; Bank of Cyprus Cultural Foundation and A.G. Leventis Foundation: Nicosia, Cyprus, 2018.

24. Barsky, B. A Pilgrim's Account of Cyprus: Bars'kyj's Travels in Cyprus. Essay, Translation, and Commentaries. In Sources for the History of Cyprus; Grishin, A.D., Wallace, P.W., Orphanides, A.G., Eds.; Greece and Cyprus Research Center: Altamont, NY, USA, 1993; Volume 3. 
25. Constantoudaki-Kitromilides, M.; Myrianthefs, D. The Church of the Virgin Podithou and the Theotokos (or the Archangel) in Galata; Bank of Cyprus Cultural Foundation: Nicosia, Cyprus, 2005.

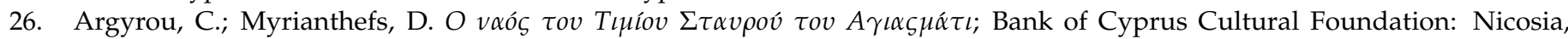
Cyprus, 2004. 